NBER WORKING PAPER SERIES

\title{
POST-ISSUE PATENT "QUALITY CONTROL": A COMPARATIVE STUDY OF US PATENT RE-EXAMINATIONS AND EUROPEAN PATENT OPPOSITIONS
}

\author{
Stuart J. H. Graham \\ Bronwyn H. Hall \\ Dietmar Harhoff \\ David C. Mowery \\ Working Paper 8807 \\ http://www.nber.org/papers/w8807
NATIONAL BUREAU OF ECONOMIC RESEARCH
1050 Massachusetts Avenue
Cambridge, MA 02138
February 2002

We are grateful to the STEP Board of the National Research Council, Washington, DC, for financial support of this project. We also appreciate helpful comments by Robert Blackburn, Wesley Cohen, Markus Herzog, Mark Lemley, Richard Nelson, Cecil Quillen, F. M. Scherer, Rosemarie Ziedonis and seminar audiences in Berkeley, Cambridge (Mass.), Heidelberg, Munich and Washington, D.C. The views expressed herein are those of the authors and not necessarily those of the National Bureau of Economic Research.

(C) 2002 by Stuart J. H. Graham, Bronwyn H. Hall, Dietmar Harhoff and David C. Mowery. All rights reserved. Short sections of text, not to exceed two paragraphs, may be quoted without explicit permission provided that full credit, including (C) notice, is given to the source. 
Post-Issue Patent "Quality Control": A Comparative Study of US Patent Re-examinations and European Patent Oppositions

Stuart J. H. Graham, Bronwyn H. Hall, Dietmar Harhoff and David C. Mowery

NBER Working Paper No. 8807

February 2002

JEL No. K41, L00, L20

\begin{abstract}
We report the results of the first comparative study of the determinants and effects of patent oppositions in Europe and of re-examinations on corresponding patents issued in the United States. The analysis is based on a dataset consisting of matched EPO and US patents. Our analysis focuses on two broad technology categories - biotechnology and pharmaceuticals, and semiconductors and computer software. Within these fields, we collect data on all EPO patents for which oppositions were filed at the EPO. We also construct a random sample of EPO patents with no opposition in these technologies. We match these EPO patents with the "equivalent" US patents covering the same invention in the United States. Using the matched sample of USPTO and EPO patents, we compare the determinants of opposition and of re-examination. Our results indicate that valuable patents are more likely to be challenged in both jurisdictions. But the rate of opposition at the EPO is more than thirty times higher than the rate of re-examination at the USPTO. Moreover, opposition leads to a revocation of the patent in about 41 percent of the cases, and to a restriction of the patent right in another 30 percent of the cases. Re-examination results in a cancellation of the patent right in only 12.2 percent of all cases. We also find that re-examination is frequently initiated by the patentholders themselves.
\end{abstract}

Stuart J. H. Graham

UC Berkeley

Dietmar Harhoff

Ludwig-Maximilians-Universitat Munchen and CEPR
Bronwyn H. Hall

UC Berkeley and NBER

bhhall@econ.berkeley.edu

David C. Mowery

UC Berkeley and NBER

mowery@haas.berkeley.edu 


\section{INTRODUCTION}

Beginning in the 1980s, a series of administrative, judicial, and legislative actions strengthened the economic value of U.S. patents and extended their coverage in such areas as computer software and "business methods." Although many of these actions were undertaken at the behest of the U.S. business community, concerns have been raised since the early 1990s about the potential economic burdens of low-quality patents in an environment of greater deference to the rights of the patentholder (Merges 1999; Barton 2000). A number of experts have suggested that the U.S. patent examination system does not impose a sufficiently rigorous review of patent and nonpatent prior art, resulting in the issue of patents of considerable breadth and insufficient quality. Many of these critics advocate the reform or extension of procedures that would enable interested parties other than USPTO examiners to bring relevant information to bear on this process either before or shortly after the issue of a patent. But much of this debate has occurred in an empirical vacuum. Little is known about the characteristics or effectiveness of existing procedures for such post-issue challenges within the U.S. patent system, and virtually no research has compared the characteristics or effects of U.S. post-issue challenge procedures with those available elsewhere in the industrialized world's patent systems.

At present the primary procedure for such a challenge to the validity of a U.S. patent is the "reexamination" proceeding, which may be initiated by any party during the life of the patent. A more elaborate and adversarial procedure in the European Patent Office (EPO) is the opposition process. This paper uses new data in an exploratory comparative analysis of these post-issue challenge proceedings, pursuing two main questions:

1) What are the determinants of post-issue challenges to the validity of patents in the United States and Europe? ${ }^{1}$

2) How do patents pertaining to the same invention fare in the two different systems?

In answering these questions, we use data from both the European and the United States Patent Offices, including a newly created dataset of "twin" patents, that is, patents taken out in both jurisdictions on the same invention.

The institutions that allow for post-grant challenges of patent validity differ considerably between the U.S. and Europe. An important feature of the proceedings at the European Patent Office (EPO), the significance of which has been remarked upon widely by practitioners but minimally analyzed, is the "opposition process." ${ }^{2}$ For nine months following the issue of a patent by the European Patent Office (EPO), interested parties can contest its validity by filing an opposition. Typically, opponents argue that an issued patent is invalid because it fails to meet the standard requirements of patentability (novelty, inventive step, industrial application, non-

\footnotetext{
We use the terms European patents or opposition in Europe as short-hand descriptions for patent applications, grants, and challenges administered by/at the European Patent Office. Strictly speaking, a European patent (that is, a patent valid throughout Europe) does not exist, since patent rights are defined within the respective national law. Despite some harmonization, these laws are still heterogeneous.

2 The opposition process at the EPO resembles the opposition process at the German Patent Office. The frequency of opposition is also quite similar.
} 
prejudicial disclosures) or the patent does not disclose the invention with sufficient clarity or completeness. ${ }^{3}$ In response to an opposition, the EPO may reject the opposition, amend the patent, or revoke the patent entirely. ${ }^{4}$

Patents issued by the EPO designate the European states in which the applicants wish to patent their inventions. Since EPO patent applications cost roughly three times as much as national applications in most European states, the EPO patents have significant cost advantages for inventions requiring protection in a number of European markets. But the centralization of application and examination also allows a centralized legal challenge: under the European Patent Convention (EPC), any third party can use an opposition proceeding to challenge the granted patent within nine months after the granting date for all of the designated states, rather than having to pursue legal proceedings in each of the European nations designated in the patent. The EPO opposition process has been cited by Merges (1999) as a more effective means of ensuring "high quality" patents, especially in novel technological areas, than those available in the United States.

U.S. patents are issued on the basis of criteria that are broadly similar to those employed by the EPO. The reliance by the US Patent and Trademark Office (USPTO) on searches of "prior art" that are frequently confined to prior patents, however, means that in areas such as computer software or biotechnology, a lack of patent-based prior art can result in the issue of patents of dubious merit or quality. Interested parties wishing to challenge a U.S. patent after its issue have two options: (1) Challenge the patent in federal court; or (2) Request a "re-examination" of the patent by the USPTO. In absolute terms, patent litigation has grown significantly in the United States during the period from 1985 to 2000, although the rate of litigation relative to the number of issued patents has remained constant. But, as we suggest below, litigation is a costly and timeconsuming means for establishing the validity and/or claims of a patent. In addition, costly patent litigation may contribute to growth in "defensive" patenting, another resource-intensive process with limited social returns (Hall and Ziedonis, 2001).

The patent re-examination procedure was created by federal legislation during the 1980s. The number of annual re-examination requests grew from the mid-1980s through the early 1990s, but has scarcely grown since 1994. Unlike litigation or oppositions, the re-examination process is not an adversarial proceeding in which advocates for each side introduce evidence and arguments in support of their position, and there are limits on the types of issues that can be raised within a reexamination. Moreover, Merges (1999) points out that the requirement that any opposition be filed within nine months of the issue of an EPO patent means that the validity of EPO patents is determined at a much earlier point in their term than is true of the re-examination or litigation processes. ${ }^{5}$ Merges estimates that almost $7 \%$ of EPO patents trigger opposition proceedings, while only $0.3 \%$ of U.S. patents result in re-examination requests. In addition, oppositions result in much higher rates of patent revocation than do re-examinations. According to Merges, more than $34 \%$ of oppositions filed in 1995 resulted in the revocation of the relevant EPO patent,

\footnotetext{
Article 100 EPC

Article 102 EPC

Balanced against this is the fact that EPO patents take longer to issue than U.S. patents, so the median lag between patent application and opposition challenge is in fact longer than the median re-examination lag in our data (see Table 1).
} 
considerably higher than the $12 \%$ of re-examination requests producing a similar result in U.S. patents during this period. ${ }^{6}$

In this paper, we report the results of the first comparative study of the determinants and outcomes of patent oppositions in Europe and of re-examinations on corresponding patents issued in the United States. Our analysis focuses on two broad technology categories biotechnology and pharmaceuticals, and semiconductors and computer software. ${ }^{7}$ Within these fields, we collected data on all EPO patents for which oppositions were filed at the EPO. We then constructed a random sample of EPO patents in these technology classes that triggered no opposition proceedings. We matched these EPO patents with the "equivalent" USPTO patents covering the same invention in the United States. This approach allows us to compare the postissue quality control processes for technologically identical patents. Using the sample of matched USPTO and EPO patents, we compare the determinants of either opposition or re-examination.

We explore issues related to the first main topic of the paper by addressing the following questions:

1. How does the rate of opposition (number of oppositions/all issued patents) vary by patent class within the EPO data, and similarly for USPTO re-examinations? Which EPO and USPTO patent classes exhibit the highest opposition and re-examination rates, respectively?

2. What are the outcomes of the opposition and the re-examination processes? Do the two procedures consistently lead to a large number of patent revocations or amendments? Do types of outcomes differ significantly with the characteristics of the patent or characteristics of the patent owner or the challenger? For example, is there any evidence suggesting that patents owned by "independent inventors" are more likely to be challenged than patents owned by corporations? ${ }^{8}$

3. How do the lengths of the average opposition re-examination processes compare? What is the total time lag between application date and resolution of legal disagreements? Do

6 See Merges (1999), pp. 612-614. Our data focus on selected technical fields and show similar numbers: we find a slightly lower opposition rate over the whole period 1980-1999 and a higher revocation rate, once the results of appeals are taken into account.

7 The IPC classes included were A61K (except A61K/7), C07G, C12M, C12N, C12P, and C12Q (biotechnology/pharmaceutical) and G01R, G06F, G06K, G11C, H01L, H03F, H03K, H03M, and H04L (semiconductors/computers/software).

8 The U.S. re-examination process was altered considerably during Congressional consideration in response to pressure from the "independent inventor" community within the United States, and there is some reason to believe that any effort to strengthen the re-examination process or institute an opposition proceeding would encounter considerable opposition from this group. Much of the group's opposition to such changes stems from the belief by many independent inventors that stronger re-examination or opposition proceedings would significantly raise the costs of patenting, because of the added costs of defending patents within these proceedings. Accordingly, information on the incidence of re-examination and opposition proceedings among different classes of patentholders will shed light on the likelihood that a disproportionate share of any such increased costs would be borne by the independent inventor. 
oppositions, for example, enable a faster resolution of issues of patent quality and/or validity?

Using our matched sample of patents, we address the second main topic (see above) by investigating the following questions:

1. Do EPO oppositions and US re-examinations focus on relatively "important" patents, measured in terms of citations to these patents in subsequent patents? How do the US patents that match opposed EPO patents compare to the US control sample (equivalents to unopposed EPO patents) in terms of the number of post-issue citations?

2. Do we observe significant differences in the probability that a US patent corresponding to an EPO patent for which an opposition is filed will be challenged through a reexamination request or through litigation, by comparison with patents in the U.S. "control samples"?

More broadly, we wish to use this preliminary analysis as one component of an assessment of the comparative cost and efficiency of the re-examination and opposition processes, including a comparison of the costs, outcomes, and duration of these processes with those of litigation. This more ambitious goal is beyond the scope of the current paper because of the lack of US and European litigation data. Nevertheless, the results reported here provide a useful starting point for the broader analysis.

\section{INSTITUTIONAL BACKGROUND}

At present, the U.S. and European patent systems have similar aims and requirements for patentability, but differ in the allowable subject matter and in their administrative procedures. In this and the next section of the paper, we provide a brief overview of the operations of the two systems.

In the United States, an invention ("process, machine, manufacture or composition of matter") must satisfy three requirements to be patentable: novelty, usefulness, and non-obviousness. Since 1978, firms and individuals have been able to submit a single application to the European Patent Office that specifies up to 19 national jurisdictions within Europe where they desire patent protection for an innovation. The patentability requirements are broadly similar but not identical to those of the United States: novelty, industrial application, and inventive step. The last two are similar but not identical to the U.S. requirements of "usefulness" and "non-obviousness."

Figure 1 shows a rough timeline covering the period between patent application and grant in the two systems. During the period covered by our dataset, the U.S. patent application was kept secret until the patent issued, which meant that the median time between application and publication was 18 months to two years, with a long tail. As part of the patent system harmonization called for in the TRIPS agreements, the U.S. instituted a policy of publication 18 months after application in November 2000 for many patents with applications pending in 
jurisdictions outside the United States. ${ }^{9}$ In contrast, EPO applications have always been published with an 18-month lag, regardless of whether they have issued.

Both systems have a post-grant procedure through which the validity of the patent can be challenged by other parties, but the two patent systems' post-grant challenge procedures differ significantly. In both systems, interested parties can also bring suit in court over infringement and validity (with some restrictions as to when a suit can be filed). We discuss these administrative processes for post-grant challenges in the following section.

\section{THE ADIMISTRATIVE PROCESSES AT THE USPTO AND EPO}

\subsection{USPTO Examination and Re-Examination Procedures}

In the United States, inventors may claim a utility patent ${ }^{10}$ by making application to the United States Patent and Trademark Office (USPTO). Before a patent issues, the USPTO is charged with ensuring that the invention covers patentable subject matter ${ }^{11}$ and is useful, ${ }^{12}$ novel, ${ }^{13}$ and nonobvious. ${ }^{14}$ Procedurally, the application must be filed within one year of the invention's public use or publication, ${ }^{15}$ must contain an adequate description with one or more claims, ${ }^{16}$ and must be accompanied by the payment of a fee. ${ }^{17}$

The USPTO patent examiner is the arbiter of the patentability, novelty, usefulness, and nonobviousness requirements cited above, judging these standards against the "prior art," i.e., prior inventions, in the field. Prosecution of the patent has been characterized as a "give-and-takeaffair," with negotiation and re-negotiation between the patentee and the examiner that ordinarily continues for 2-3 years (Merges, et al., 1997). The costs of prosecuting a patent through the

9 The American Inventors Protection Act (1999) requires publication of all applications after 18 months but excepts applicants making a declaration that a patent will not be sought in a foreign jurisdiction requiring 18 month publication. 35 USC $\S 122$.

10 While the vast majority of US patents--and the focus in this paper--are the so-called Utility patents authorized by 35 USC §101, patents are also available on Plants (35 USC §161) and Designs (35 USC §171).

1135 USC §101. See Diamond v. Chakrabarty, 447 US 303 (1980)(determining that man-made living microorganisms are patentable subject-matter).

1235 USC §101. See Brenner v. Manson, 383 US 519 (1966)(upholding examiner's determination that a the output of a chemical process was not useful if merely similar to a useful compound).

1335 USC §101, 102. See Jamesbury v. Litton Industrial, 756 F.2d 1556 (CAFC 1985)(finding that an invention was "novel" when no prior art was precisely equivalent).

1435 USC §103. See Graham v. John Deere Co., 383 US 1 (1966)(finding an invention invalid on grounds that the improvement would have been obvious to a person of ordinary skill in the art).

1535 USC $\$ 102(b)$.

1635 USC $§ 112,113,114$. The "written description" requirement is intended to allow any person skilled in the art to either make or use the invention. See Permutit v. Graver Corp., 284 US 52 (1931), finding that the absence of any writing was an insufficient description when only drawings were provided. Claims are intended to delimit the subject-matter that constitutes the invention. See Flick-Reedy Corp. v. Hydro-Line Mfg., 351 F.2d 546, 7th Cir. 1965, holding that withholding information from the claims failed to adequately describe the invention.

17 USPTO regulations set the basic filing fee at $\$ 710$ for utility patents. 37 CFR $\$ 1.16(a)$. Additional claims may raise the fees payable, and all fees are generally lower for "small entities." . 37 CFR §1.16(b),(c),(d). 
USPTO range from $\$ 15,000-\$ 100,000$ (including the USPTO issue fee), depending on the nature of the technology. ${ }^{18}$

Reexamination, originally envisioned as an alternative to expensive and time-consuming litigation, was created by the 1980 Act to Amend the Patent and Trademark Laws. The legislative history of this Act suggests that the reexamination was intended to be a mechanism that would be less expensive and less time-consuming ${ }^{19}$ than litigation. During the legislative process, however, the $\mathrm{Act}^{20}$ was purged of its intended adversarial characteristics under pressure from various interest groups (notably, the independent inventor lobby), reducing the usefulness of the procedure for opponents of a given patent.

Procedurally, the reexamination proceeding permits the patent owner or any other party to notify the USPTO and request that the grounds upon which the patent was originally issued be reconsidered by an examiner. Initiation of a reexamination requires that some previously undisclosed "new" and relevant piece of prior art be presented to the agency. Under the statute, this new prior art must be disclosed in either a prior patent or prior publication-no other source of prior art can serve as grounds for the reexamination.

After being initiated by the proponent through a notification and the payment of a fee to the USPTO, ${ }^{21}$ the reexamination goes forward only if the Patent Office finds a "substantial new question of patentability." ${ }^{22}$ Such a determination was intended by lawmakers to prevent the reopening of issues deemed settled in the original examination (Merges, 1997). The Patent Office must make this determination within 3 months of the request, and, having made the determination, must notify the patent owner.

When the owner is not the reexamination proponent, the patentee is allowed to file a response to the newly discovered prior art within 2 months. If the owner chooses to respond, the requester is afforded an opportunity to reply within 2 months. By choosing not to respond, the owner can limit the requester's participation in the process. Under the most favorable circumstances, the reexamination is essentially an ex parte proceeding between the patent owner and the Patent Office, with limited opportunities for third-party involvement.

Any third party, such as a competitor or other opponent of the patent, thus has a limited role in the re-examination process. The requester is entitled to notify the USPTO of the triggering "prior art," to receive a copy of the patentee's reply to the reexamination (if any), and to file a response to that reply. The owner's role in the process is much more involved: the reexamination statute contemplates a second examination, with the same type of "give and take" negotiation between owner and patent office which occurs during the initial issuance of a patent. The examiner remains the final arbiter of the process and it is not uncommon for the original examiner to be

18 Gable and Montague (2001); utility issue fees have been set at \$1,240. 37 CFR §1.18(a).

19 Our evidence suggests that the average reexamination takes less than two years, slightly shorter than the average duration of a patent lawsuit (31 months). But this difference is not large (especially in view of the high variance of the "average duration" estimate for a trial), some observers have criticized the reexamination system for not having provided a fast and cheap alternative to trial.

20 "Act to Amend the Patent and Trademark Laws," Pub.L.No. 96-517, 94 Stat. 3015 (1980).

$21 \$ 2,520$ in 2001. 37 CFR $\$ 1.20(\mathrm{c})$.

2235 USC $\$ 303$. 
assigned the follow-up reexamination, thus putting the question of whether prior art was overlooked in the hands of the same government official responsible for ensuring that no prior art was overlooked in the previous search.

Once the reexamination goes forward, however, the statute requires that the Commissioner make a validity determination. ${ }^{23}$ The original patent is afforded no statutory presumption of validity in the proceeding, although the practice of assigning reexaminations to the original examiner may produce such a de facto presumption. The reexamination may be neither abandoned nor postponed awaiting the result of concurrent litigation proceedings. ${ }^{24}$ The result of the reexamination may be a cancellation of either all or some of the claims, or the confirmation of all or some of the claims. Nothing in the reexamination procedure can expand the scope of the original patent's claims, but claims may be amended or new claims added during the renegotiation between the patent owner and the examiner.

In summary, for parties seeking to invalidate an issued patent, the reexamination procedure involves considerable costs and risks. The filing fee for the reexamination is not insubstantial, and practitioners estimate the average costs of a reexamination costs at $\$ 10,000-\$ 100,000$ depending upon the complexity of the matter. Although the costs of a re-examination are lower than litigation ( $\$ 1-3$ million), the third-party challenger in re-examination is denied a meaningful role in the process, and the patentholder maintains communications with the examining officer, offering amendments or adding new claims during the reexamination. Reexamination also may create additional barriers for challengers seeking redress in court because the Court of Appeals for the Federal Circuit has given added weight to the claims confirmed by the reexamining officer. ${ }^{25}$. As a result, challengers face powerful incentives to forego reexamination in favor of litigation, a process that may well be more expensive, more time-consuming, and less expert for testing post-issue validity.

\subsection{Patent Litigation in the United States}

In the United States, post-issue validity can also be tested in court. The U.S. federal courts obviously are a unified system operating under the same substantive legal requirements, in contrast to the multi-state system facing litigants in Europe. Because patent suits are filed at the district court (trial) level, litigants have considerable control, e.g., through their choice of district court, over the manner in which litigation unfolds. This opportunity for control is partially mitigated by the existence of the Court of Appeals for the Federal Circuit, which hears all patent appeals. But a very small percentage of patent cases are appealed to the CAFC, which means that any differences in judicial philosophy among the many U.S. district courts may influence the outcomes of litigation. ${ }^{26}$

Procedurally, litigation differs markedly from the reexamination procedure. Unlike the reexamination procedure, litigation is an adversarial appeal to a court-arbiter in which the litigant has a choice over the final arbiter of the dispute, and may elect to have the case heard by either a

\footnotetext{
35 USC $\S 307$. There is no time limit on the duration of a reexamination per se.

Although reexaminations may be stayed during other USPTO proceedings, including reissue or interferences.

Kaufman Company v. Lantech, Inc., 807 F.2d 970 (CAFC, 1986).

26 Although it is likely true that more valuable patents are more likely to be the subject of an appealed trial verdict.
} 
judge or a jury. Because patent suits generally arise from a charge of infringement by the patent owner, the patentee exerts considerable control over the timing of enforcement and litigation in a patent dispute. $^{27}$

Legal standards create a relatively hostile environment in the Federal Courts for challengers seeking to invalidate an issued patent. Under the statute, patents are "born valid," enjoying a strong presumption of validity during the court proceedings. ${ }^{28}$ Furthermore, the evidentiary standard for proving a claim invalid is "clear and convincing" evidence, a standard considerably higher than the mere "preponderance" of proof required in the typical civil suit. Because judges and juries may have limited technical expertise, these presumptions and evidentiary barriers create high costs for challengers. The pro-patent environment signaled by the creation of the Court of Appeals for the Federal Circuit has compounded these barriers: according to one study, successful challenges to patent validity fell from $50 \%$ to $33 \%$ in the years after the creation of the Court (Lemley and Allison, 1997).

Direct costs in litigation are also high compared to reexamination. Estimates of legal costs in patent litigation run from $\$ 1-3$ million per suit (AIPLA, 1999) to $\$ 500,000$ per claim at issue, per side (Barton, 2000). One important driver of these costs is the extensive use of pre-trial discovery. The lag between filing a patent suit and reaching a resolution can also be considerable: one study estimates the average length of a district court patent suit at 31 months (Magrab, 1993). These relatively high costs and long lags have led a number of scholars (e.g., Merges, 1999) to argue that a stronger post-grant challenge system could reduce uncertainty regarding the validity of individual patents and, arguably, contribute to higher patent quality, in a less expensive and time-consuming manner. As we noted earlier, the adversarial elements originally contained in the legislation that established the U.S. re-examination system were largely removed this procedure during Congressional debate of the bill. In contrast, adversarial processes form the basis for the "opposition" procedure adopted by the European Patent Office.

\subsection{EPO Examination and Opposition Procedures ${ }^{29}$}

Patent protection for European member states can be obtained by filing several national applications at the respective national patent offices or by filing one EPO patent application at the European Patent Office. The EPO application designates the EPC ${ }^{30}$ member states for which patent protection is requested. The total cost of a European patent amounts to approximately $€ 29,800$, roughly three times as much as a typical national application. ${ }^{31}$ Thus, if patent

27 This owner-initiation occurs in many cases in which declaratory validity determinations are being sought by a challenger $-3^{\text {rd }}$ party: these suits which make the patentee the defendant are often initiated only after a demand by the patent holder to the challenger to stop infringing the patent, thus putting the initial move in the hands of the patent holder.

2835 USC $\$ 282$

29 This section is largely based on the description of the EPO examination and opposition system in Harhoff and Reitzig (2001).

30 The Convention on the Grant of European Patents, also referred to here as the European Patent Convention (EPC) was enacted in October of 1973. It is the legal foundation for the establishment of the EPO. The full text of the convention is available at http://www3.european-patent-office.org/dwld/epc/epc 2000.pdf.

31 As in other patent systems, the official patent office fees are a relatively small part of the costs (in this case $€ 4,300$ ). Professional representation before the EPO amounts to $€ 5,500$ on average, while translation into the languages of eight contracting states requires $€ 11,500$. Renewal fees for a patent maintained for ten years 
protection is sought for more than three designated states, the application for a European patent is less expensive than independent applications in several jurisdictions. This cost advantage has made the European filing path particularly attractive for applicants selling goods and services in multiple European markets. Increases in the number of patent applications and grants have given the European Patent Office a level of economic importance that now resembles to that of the United States Patent and Trademark Office (USPTO).

EPO patent grants are issued for inventions that are novel, mark an inventive step, are commercially applicable, and are not excluded from patentability for other reasons. ${ }^{32}$ After the filing of an EPO application, a search report is made available by the EPO to the applicant. The search report is generated by EPO's search office in The Hague and then transferred to the examining staff in the Munich office. The search report describes the state of prior art regarded as relevant according to EPO guidelines for the patentability of the invention, i.e., it contains a list of references to prior patents and/or non-patent sources. ${ }^{33}$ Within six months after the announcement of the publication of the search report in the EP Bulletin, applicants can request the examination of their application. This request is a compulsory prerequisite for the patent grant. If examination is not requested, the patent application is deemed to be withdrawn. Eighteen months after the priority date the patent application is published. At this point, the application is normally under examination; thus, the patent owner is generally required to reveal some information about his/her invention prior to the grant of the patent even if no patent is ever issued.

After examination (if requested) has been performed, the EPO presents an examination report. At this point, the EPO either informs the applicant that the patent will be granted as specified in the original application or requires the applicant to agree to changes in the application that are necessary to grant the patent. In the latter case, a negotiation process similar to that in the US system may ensue. Once the applicant and EPO have agreed concerning the scope of the allowable subject matter, the patent issues for the designated states and is translated into the relevant national languages. If the EPO declines to grant a patent, the applicant may file an appeal. ${ }^{34}$ On average, the issue of a European patent takes about 4.2 years from the date of filing the application (Harhoff and Reitzig, 2000). Within nine months after the patent has been granted, any third party can oppose the European patent centrally at the European Patent Office by filing an opposition against the granting decision. The outcome of the opposition procedure is binding for all designated states. If opposition is not filed within nine months after the grant, the patent's validity can only be challenged under the legal rules of the respective designated countries, some of which have their own opposition proceedings.

The EPO opposition procedure thus is the only centralized challenge process for European patents. An opposition to a European patent is filed with the EPO. The opponent has to substantiate his opposition by presenting evidence that the prerequisites for patentability were

amount to roughly $€ 8,500$. See "Cost of an average European patent as at 1.7.99“, http://www.european-patentoffice.org/epo/new/kosten e.pdf (Jan. 14, 2002).

32 See Article 52 EPC.

33 It is important to note that applicants at the EPO are not required to supply a full list of prior art - as it is the case in the US system. See Michel and Bettels (2001, 191f.).

34 See Article 106 EPC. Any decisions made by the EPO receiving, examining, opposition sections and legal division can be appealed and the appeal has suspensive effect. 
not fulfilled, e.g., the opponent must show that the invention lacked novelty and/or an inventive step, or that the disclosure was poor or insufficient. At the EPO, an opposition division determines the outcome. The examiner who granted the patent is a member of the three-person opposition chamber, but may not be the chairperson. The opposition procedure can have one of three outcomes: the patent may be upheld without amendments, it may be amended, ${ }^{35}$ or it may be revoked. ${ }^{36}$ As we pointed out earlier, revocation occurs in about one third of all opposition cases. $^{37}$

Another interesting aspect of the opposition procedure concerns the restrictions imposed by this process on the opponent's ability to settle "out of court". Once an opposition is filed, the EPO can choose to pursue the case on its own, even if the opposition is withdrawn. ${ }^{38}$ Thus, the opponent and patentholder may not be free to settle their case outside of the EPO opposition process once the opposition is filed. This provision of the opposition proceeding may discourage its use by opponents seeking to force patentholders to license their patents.

Both the patentholder(s) and the opponent(s) may appeal the outcome of the opposition procedure. $^{39}$ The appeal must be filed within two months after receipt of the decision of the opposition division, and it must be substantiated within an additional two months. The Board of Appeal affords the final opportunity at the EPO to test the validity of the contested European patent. Both parties can bring expert witnesses into the proceedings, and there are various options for having deadlines extended. For the two technical fields considered in this paper, the median duration of the challenge procedures (opposition and any appeal ${ }^{40}$ ) is 3.07 years, although there is considerable variation in the duration of individual cases (the interquartile range is 2.8 years).

The official fee for filing an opposition is $€ 613$; for filing an appeal against the outcome of opposition, the fee is $€ 1022$. But the total costs to an opponent or the patentholder are much higher. Estimates by patent attorneys of the costs of an opposition range between $€ 15,000$ and $€ 25,000$ for each party. Patent attorneys interviewed by us agreed that there is not much room for the opponent to drive up the patent owner's cost of litigation, since attorney fees are regulated in most European countries, including Germany, where many patent lawyers who have the required EPO registration reside.

35 See Article 99ff EPC. An amendment normally results in a reduction of the "breadth" of the patent by altering the claims which define the area for which exclusive rights are sought.

36 On average, the opposition procedure takes around 2.2 years if the patent is revoked and about 4 years if the patent is amended. See Table 2 for similar information on our samples.

37 See EPO (1999), p. 17 and Merges (1999), pp. 612-614. There are no publicly available data as to the frequency and extent of amendments, or the frequency of rejected oppositions. For the technical fields considered in this paper, we compute these figures below.

38 Rule 60 EPC: "In the event of the death or legal incapacity of an opponent, the opposition proceedings may be continued by the European Patent Office of its own motion, even without the participation of the heirs or legal representatives. The same shall apply when the opposition is withdrawn."

39 Article $99 \mathrm{ff}$. EPC

40 For the two technical fields studied in this paper, an appeal occurs in about one third of all opposition cases. 


\subsection{Patent Litigation in Europe}

Although the EPO provides a centralized application and examination process, there is no supranational or centralized process of patent litigation in Europe. The attractiveness of the EPO opposition process stems in part from the fragmentation of patent litigation processes in Europe. Unfortunately there have been very few systematic studies of patent litigation within the various European nations. We therefore confine ourselves to a brief review of the few facts that are known.

After the grant, the EPO patent becomes a bundle of national patent rights that are treated like "normal" national patents that can be attacked by third parties through legal means allowed for in the respective national legislation. Outcomes in these "local" litigation cases are restricted to the "local" level, e.g., the patent may be invalidated in Spain, but this does not affect its validity in Italy. During the past decade, national patent courts have increasingly taken evidence and decisions from litigation in other EC nations into account, but no systematic study has analyzed such legal "spillover" effects (Stauder 1996). Other spillover effects link the outcome of oppositions and those of subsequent litigation. The national authorities involved in the adjudication of these suits can refer to previous proceedings, which may make it more difficult for a plaintiff to win a national validity suit after having lost an EPO opposition proceeding. But no systematic analysis of these spillovers has yet been undertaken.

The differences among national jurisdictions within Europe are enormous, requiring substantial investments in each national suit and driving up the costs of challenging the national patents emerging from an EPO grant in several of the designated states. The costs of litigation in any national court have been estimated to be between $€ 50,000$ and $€ 500,000$, depending on the complexity of the case. This cost structure makes an attack at the European level using the opposition procedure particularly attractive for a current or potential competitor of the patentholder. The litigation rate (computed as the number of cases for which a suit is filed divided by the number of patents) in most European countries is roughly one percent, slightly lower than in the United States (Stauder 1996, 1989). But the quantitative evidence is too sparse to conclude from these figures that the existence of the opposition mechanism leads to a reduction in litigation.

\section{Extent and Determinants of Post-Issue Challenges}

\subsection{Aggregate Statistics}

This section presents some aggregate statistics on EPO patent oppositions and USPTO reexaminations during the past two decades. First we look at the rate at which these post-grant challenges are pursued for all granted patents and for our two broad technology classes. We then analyze the length of time until challenge occurs and until it is resolved. Finally, we examine the characteristics of patents that influence the frequency of post-grant challenges in our two technology classes.

Any comparison of opposition and re-examination must begin with a recognition of the fact that there are far more opposition cases (33,599 between 1980 and 1998) than re-examination cases 
$(2,949)$ during the period of this analysis. This difference reflects the fact that the re-examination proceeding operates very differently than does an opposition proceeding. Indeed, one salient difference between the re-examination and opposition procedures concerns the identity of the challengers in these processes. In nearly $44 \%$ of the re-examination cases during this period, the party initiating the proceeding is identified by USPTO as the patent's "owner." Obviously, there are virtually no circumstances under which the patentholder initiates an opposition proceeding in the EPO. Moreover, since many of the other parties initiating re-examinations are law firms that may be acting on behalf of patentholders, the share of re-examinations initiated by patentholders almost certainly approaches $50 \%$. In many cases, patentholders initiate re-examinations to address failures to properly cite prior art, correct claims, or to repair other flaws in the issued patent. But this difference between re-examinations and oppositions in the identity of the initiating parties highlights the very different roles of the re-examination and opposition procedures and underscores the need for caution in drawing analogies between these types of post-issue challenges.

Because our technology classes contain relatively few re-examination cases, much of our discussion of re-examinations in this section uses data for all U.S. re-examinations, rather than only those from our two broad technology classes. Figure 2 displays the opposition and reexamination "rates" in all technology sectors during 1980-98 (based on the year of patent grant), while Figure 3 shows the rates for our two technology classes during 1980-96. The opposition and re-examination "rate" is defined as the share of patents granted in a given year that are ultimately challenged through opposition or re-examination. Our measure of the re-examination rate is truncated because challenges can happen any time during the lifetime of a patent, ${ }^{41}$ and we use a simple model of the re-examination lag to compute a minor correction for this truncation. Two facts are immediately apparent from Figures 2 and 3:

1. The opposition rate at the EPO is much higher than the re-examination rate at the USPTO for all technology classes (Figure 2), as has been noted previously by Merges (1999) and Harhoff and Reitzig (2000). The average re-examination rate during the 1981-1998 period was $0.2 \%$ and the average opposition rate during the period was $8.3 \%$. Thus, during 1980-98 oppositions were about 40 times more likely to be filed than reexaminations.

2. The opposition rate for patents in the semiconductors, computing, and software sector is substantially lower than that for patents in the biotechnology/pharmaceutical sector and for patents in all sectors. Our two technology classes display far smaller differences in their re-examination rates, nor do their re-examination rates differ significantly from those for patents in other sectors. The lower opposition rates in semiconductors and software may reflect technological differences, but it is also plausible that firms in the semiconductor and computing industries have developed a pattern of private negotiations (e.g., cross-licensing negotiations) for resolution of some emerging disputes (Hall/Ziedonis 2001). The relatively modest inter-class differences in re-examination rates reflect the limited utility of this process for use by patent opponents or competitors.

41 Figure 4 depicts the distribution of the lag between patent application and challenge. Roughly three-fourths of the re-exam requests are filed within 8 years of the application date. Since the average pendency period for a US patent application is 2 years, this lag corresponds to approximately 6 years after the grant date. 
Figure 4 displays the distribution of the average lag between applying for a patent and the filing of a re-examination or opposition request. ${ }^{42}$ Because oppositions must be filed within 9 months of a patent grant, its lag distribution is much tighter than that for re-examinations. But the grant lag in Europe is longer, making the mean lag between application and the filing of an opposition or re-examination action similar for the two proceedings: 5.5 years elapse between the application date and initiation of an EPO opposition, only slightly less than the average lag of 6 years between patent application and a re-examination request in the United States.

Figure 5 depicts the distribution of the time lag between a patent application and final resolution of the post-grant challenge in the two systems. Since prompt resolution of uncertainty over patent validity is one potential source of welfare gain from an efficient system for post-issue challenges, the length of time from patent application to final resolution is an important criterion for evaluating the respective benefits of oppositions and re-examinations. The distributions of the duration of these proceedings differ considerably, and it is clear that the European opposition system takes somewhat longer to resolve patent disputes. The median length of time between application and final outcome of the challenge proceeding is 8.4 years at the EPO and 6.4 years at the USPTO. Confining our analysis to patents applied for before 1991, in order to minimize the effects of lag truncation, reduces the difference between these means, reflecting the more diffuse distribution of these lags at the USPTO. Nevertheless, the duration of the period from application to resolution remains longer for EPO oppositions on average than is true of reexaminations.

Table 1 summarizes the characteristics of the lag distributions that were shown in Figure 5 for the two systems. The median lag between patent application date and final opposition outcome at the EPO is two years greater than for re-examination at the USPTO for the overall time period, although this differential lag shrinks to less than one year for pre-1991 applications. The interquartile range is slightly more than one year smaller within the EPO data for the entire time period and more than two years smaller for pre-1991 applications. The EPO opposition proceedings thus are longer on average, but the variance of these lags is greater within the US reexamination proceedings. Since the re-examinations can be initiated at any time during the life of a US patent, this greater variance in the distribution of the "procedural lags" for US reexaminations is hardly surprising.

The Appendix to this paper presents two brief case studies of USPTO and EPO patents covering similar inventions that were opposed in the EPO system (in our terminology, these are "twin" patents). The cases, both of which cover biomedical inventions, indicate that parties opposing patents in the EPO may well pursue litigation simultaneously against the EPO patentholder's US patent. The cases also underscore the point made earlier about the lengthy duration of the EPO opposition system — one lawsuit in the United States over Ortho Pharmaceuticals '799 patent was settled five years before the opposition proceeding on the corresponding EPO patent reached a conclusion. The other U.S. lawsuit involving this patent, however, was not settled for two years after the conclusion of the opposition process for the EPO "twin." The other case study of the Liposome Corporation's U.S. and EPO patents reveals a similarly complex interaction between the processes of post-grant review or litigation in the U.S. and European systems. In this case, as

42 With the exception of the data in Figure 2, the EPO data are based on all oppositions in our two selected technology classes, a sample of approximately 2400 oppositions filed between 1980 and 1999. 
in the Ortho Pharmaceuticals case, a defendant in an infringement suit filed in the U.S. by Liposome Corporation was engaged as an opponent to the Liposome Corporation's EPO patent. This case also highlights the strategic use by a patentholder of the U.S. re-examination process to (apparently) strengthen its claims and weaken the position of a competitor. The cases thus indicate considerable interdependence between the EPO opposition process and post-grant challenges in the United States. The dimensions and timing of this interdependence are an important topic for future research.

Summarizing our descriptive findings, the EPO opposition system does not reach a conclusion more rapidly than the US re-examination procedure, when this procedural duration is estimated as the length of time from patent application date to final resolution. The average lag between application date and the initiation of a challenge is substantially greater within the U.S. reexaminations than in the EPO oppositions, but this difference reflects the different time limits on the initiation of such proceedings (the EPO requirement that opposition be filed within 9 months of patent grant). Should we conclude from these comparative data that the longer lags in the EPO opposition system imply a lengthier period of uncertainty, legal expense, and therefore, a higher welfare burden within the innovation systems of these economies? Such a conclusion is unfounded, since it relies on a characterization of the re-examination and opposition proceedings as analogous in their characteristics, rigor, and outcomes. The data presented above on the identity of the parties initiating re-examinations, as well as the abundant evidence discussed earlier of significant procedural differences between the re-examination and opposition processes, should dispel any such analogies. Any such comparison of challenges also must incorporate data on the next stages of these challenges, which in both Europe and the United States involve litigation. Unfortunately, the analysis of litigation data is beyond the scope of this paper.

\subsection{Analyzing the Determinants of Re-Examination at the USPTO}

What are the characteristics of the U.S. patents that undergo re-examination? Do they differ from the characteristics that have been identified as determinants of EPO opposition challenges in the study by Harhoff and Reitzig (2001)? To address these questions, we analyzed the characteristics of re-examined patents by analyzing patents issued between 1975 and 1999 in all patent classes for which re-examinations were requested between 1975 and 1999 (a total of 3,078 patents), comparing the characteristics of these patents against those in a $1 \%$ sample of all U.S. patents issued during this period (yielding a "control sample" of 23,444 patents). In order to deal with truncation issues, we also analyzed a sample of pre-1991 patents from each system (a sample including 2058 re-examined patents and 12,160 control patents).

The results for our probit regressions analyzing the determinants of re-examinations of all U.S. patents, which use variables similar to those used by Harhoff and Reitzig (2000), are shown in Table 2. The first panel shows results for the whole 1975-1999 sample, while the second panel restricts the sample to patents granted before 1991, because our measure of forward citations (those during the first 9 years of patent life) is truncated for patents issued in the 1990s. The variables have fairly high predictive value, with a pseudo R-squared of about 0.15 and an error rate of about $13-17 \%$ compared to $23 \%$ for random assignment. 
Similarly to the findings of Harhoff and Reitzig in their analysis of oppositions, we find that reexamination requests are more likely for patents that are cited more frequently by other patents following their issue. Patents owned by individual inventors are no more likely to be reexamined than those held by corporations. Patents held by government entities are about 8-11 percent less likely to be reexamined, ceteris paribus.

As we noted earlier, our data include re-examinations in all technology classes, in contrast to the analysis of oppositions by Harhoff and Reitzig. Our analysis of re-examinations of patents in the classes examined by Harhoff and Reitzig indicates that biotechnology/pharmaceutical patents are no more likely to be re-examined and patents in the semiconductor, computer hardware and software classes are less likely to be re-examined, by comparison with patents overall. ${ }^{43}$ For patents granted prior to 1991, both biotechnology/pharmaceuticals and semiconductor/computer hardware have re-examination rates that are approximately the same as those for other industries. Only software is lower, by about 8 percent, although sample sizes are small.

The nationality of the patentholder has little effect on the likelihood of re-examination, although patents held by U.S., Canadian, Australian, or Israeli assignees are slightly more likely to be reexamined. Finally, the results for dummy variables indicating the number of claims in the patent suggest that the probability of re-examination rises monotonically with the number of claims; more complex patents are more likely to be re-examined.

\subsection{Re-examination Outcomes}

Table 3 summarizes the results of re-examinations conducted by the USPTO between 1980 and 1999. The top panel shows all 3127 re-examinations for which we have outcome information and the bottom panel shows the results for our two main technology classes. ${ }^{44}$ The proportions are similar, although claim amendment appears to be more likely than the mere addition or cancellation of claims in our two technology classes, both of which cover relatively new areas of inventive activity.

About 24 per cent of the patents are confirmed in full on re-examination, while only about 10 percent are revoked in full, a number similar to the 12 percent reported by Merges (1999) for 1995. For the newer technologies, confirmation in full is less likely and revocation more likely. The next section compares the results of re-examination to those achieved by the EPO opposition system for these two technology classes.

\subsection{Sampling Strategy for US-EPO Equivalents}

43 Looking at the detailed classes, the following are less likely to be re-examined: C12P (fermentation or enzymeusing processes), G06F (electronic digital processing), and H01L (semiconductor devices). More likely to be reexamined are H03K (electronic switching (pulse) devices), G11C (static information storage), and H03F (amplifiers).

44 The sample of outcomes is slightly larger than the sample of re-examinations used in Table 2 because a few observations were deleted from the sample used in Table 2 due to missing data problems. 
Thus far, we have examined data on the determinants of re-examinations at the USPTO. We now examine the similarities and differences between the US and European challenge systems, both in terms of the characteristics of patents that trigger challenges and in terms of the outcomes of these challenges. This analysis requires that we control for possible differences between US and EPO patents. To that end, we assembled a dataset that includes "twins," i.e., EPO patents that are also issued in the United States or vice versa.

Assembling this dataset of "twin" patents relied on a sampling strategy that could produce a set of US-EPO "twins" and control samples that are similarly distributed among years and technology classes within the U.S. and EPO patent data. We used the International Patent Classifications for our patents, since it is employed by both the USPTO and the EPO. We based our sampling strategy on the IPC classifications done at the European Patent Office, since these assignments are more reliable than the IPC assignments done after the fact at the USPTO. ${ }^{45} \mathrm{We}$ began by drawing a sample of approximately 2,000 EPO patents that met the following criteria (Figure 6 provides a graphic depiction of this sampling strategy):

- They were granted between 1980 and 1997 (applied for between 1978 and 1995).

- They were classified in one of our two broad technology classes $(62 \%$ in biotechnology/pharmaceuticals and 38\% in semiconductors/computers/software).

- An opposition was filed against them after grant.

These patents are shown in the upper left hand corner of Figure 6. Using these 2,027 patents as our sampling frame, we then drew an $8 \%$ sample of unopposed EPO patents in these technology classes to use as controls in our analysis of oppositions, stratifying on the filing date (month and year) and IPC class, yielding a total of 2,861 patents. These are shown in the upper right hand corner. Because biotech/pharma patents are opposed at a higher rate, our $8 \%$ sample of unopposed patents yields a smaller control sample. ${ }^{46}$

U.S. equivalents for these two samples of patents (Equivalents are members of the same patent family which have exactly the same priority or priorities in common) were then collected, yielding the patents in the two bottom panels. ${ }^{47}$ In about 2-3 percent of the cases, an EPO patent has more than one U.S. equivalent; three patents have more than 3 US equivalents. The likelihood that an EPO patent has a USPTO equivalent is higher for semiconductor/software than for biotechnology and pharmaceuticals. We have no explanation for this difference at present. It may reflect a greater tendency for patent applicants to pursue national rather than global IP protection strategies in biotechnology and pharmaceuticals, or it may reflect a greater presence of non-industrial assignees (universities and government laboratories, both of whom

${ }^{45}$ This conclusion is based on private communications from more than one U.S. Patent Examiner. The search system at the USPTO is based on the U.S. patent classification system and IPCs are assigned only after the fact, based on a rough concordance.

46

16 patents in the EPO opposed sample and 3 in the control sample described in Section 4 had twins that encountered re-examination requests, implying re-exam probabilities of $1.6 \%$ and $0.15 \%$ respectively. This means the re-exam probability is ten times as high for opposed patents, but still very small overall.

47 See $\mathrm{http} / / \mathrm{gb}$.espacenet.com/espacenet/gb/en/help/161.htm for definitions of patent families and equivalents. Equivalents can be identified using the ESPACENET service of the European Patent Office. This database is available at http://ep.espacenet.com. 
are less likely to pursue global filings) in the biotechnology and pharmaceuticals patent databases. But these possibilities are purely speculative, and additional analysis of our data is needed.

The probability that an EPO patent has a U.S. equivalent is also higher for the controls than for the opposed patents, even when we control for broad technology class. It is possible that this result reflects interdependence between the EPO oppositions and patent filings in the US system. For example, a an applicant receiving a relatively "weak" USPTO patent may be less likely to file for an EPO patent, simply because of the nonzero probability that an opposition to the EPO patent could result in the revocation or significant amendment of the EPO patent. But this issue requires additional analysis.

\subsection{Incidence of Opposition}

Table 4 displays the results of a series of probit regressions that relate the probability that a patent is opposed in the EPO system to the characteristics of the patent, its assignee, and the U.S. twin, if there is one. All of the right-hand variables are dummies and the estimates shown are the change in the probability if the dummy changes from 0 to 1 . The first data column of the table gives the number of observations for each variable for which its respective dummy variable was equal to one.

When we included only grant year dummies, the biotech/pharma dummy, and the U.S. twin dummy in the probit, we obtained the following estimate:

$$
\text { Prob(opposition })=\text { year effects }+0.290 \text { D(biopharm })-0.117 \text { D(U.S. twin exists })
$$

This result essentially summarizes the results of our sampling strategy: biotechnology/pharma patents are 30 per cent more likely to be opposed, and patents with U.S. twins are approximately 12 per cent less likely to be opposed. Including only these variables along with grant year dummies yielded an R-squared of 0.09 .

Columns (1) and (2) relate opposition to a number of characteristics of the patent and its holder. In column (2) we replace the biotech/pharma dummy by a full set of dummies for the 15 4-digit IPC classes we are considering. These dummies are clearly significant $\left(\chi^{2}(12)=99.5\right)$, but they have little effect on the estimate of the other coefficients. ${ }^{48}$ The other variables in the regression are the following:

- A set of dummies for the number of EPO citations received by the patent between its issue date and 1999. One additional forward cite raises the opposition probability about 3-5 per

48 The degrees of freedom are lowered by the fact that some cells are sparse and therefore not identified in the regression. Those that had much lower opposition probability than average were G06F, G11C, H01L, H03K, $\mathrm{H} 03 \mathrm{M}$, and H04L, which are most of the semiconductor/computing classes. Those that were higher were C07G and $\mathrm{C} 12 \mathrm{M}$. This result essentially confirms the fact that the biopharm dummy captures most of the difference in opposition rates for these technologies. 
cent, with some diminishing returns, a result that is consistent with the Harhoff-Reitzig results cited earlier.

- A set of dummies for the number of EPO states in which the patent was taken out (1-5, 610 , and more than 10). Designating more states raises the probability of opposition, which again is consistent with Harhoff and Reitzig (2001).

- A set of dummies for the number of claims (1-5, 6-9, 10, 11-15, more than 15). Having more claims raises the probability of opposition, but only if the number of claims exceeds $10 .^{49}$ The meaning of this result is ambiguous, because the number of claims in a patent is itself subject to multiple interpretations. On the one hand, patents with a large number of claims could be seeking protection for a very narrowly defined invention. In other words, these patents are occupying a space in a relatively "crowded" field populated by many similar inventions, raising the probability of an opposition. On the other hand, patents with large numbers of claims are broader, rather than narrower, and may therefore face a lower probability of opposition (i.e., they could be early occupants of a less crowded invention space). The coefficient implies that the "crowding" effect, which raises the probability of an opposition, becomes significant as the number of claims in the patent exceeds 10 .

- Whether the patentholder is an independent inventor, ${ }^{50}$ a dummy variable for which the coefficient is insignificant.

- Whether an accelerated search was requested by the patent applicant at the EPO, which lowers the probability of opposition by about 14 per cent. ${ }^{51}$ Accelerated search is often requested when the applicant is unsure of the state of the art, or of whether their invention is patentable. We therefore interpret this result as indicating a relatively "low-quality" (or less important) patent that is less likely to trigger an opposition.

- Whether an accelerated examination was requested by the patent applicant, which raises the probability of opposition by 24 per cent. This request indicates that the applicant attaches high value to the patent, e.g., because a patent race is underway. As a result, it is more likely that there will be a competitor that wishes to oppose the patent.

- Filing a Patent Cooperation Treaty (PCT) application, something that enables the applicant to file for protection later in up to 80 countries at WIPO. A PCT application raises the probability of an opposition by about 10-12 per cent, which may reflect the higher value of an invention for which broad international patent protection is sought.

- A set of dummies for the country of the patentholder. Although they are jointly significant, none are significant individually. Since those for Germany and the rest of Western Europe are marginally significant, we retain them.

49 The focal point at 10 claims is apparently caused by the fact that EPO charges a separate claims fee of $€ 40$ for the eleventh and each subsequent claim (Rule 31, 51 and 101 EPC).

50 This variable disagrees with the U.S. assignment code for the twin in about one third of the cases, which seems unlikely to us. Some of the differences occur because the EPO records multiple owners for the same patent, both individual and corporate, where the USPTO records only the corporation (or university, in many of these cases). We include both the US and the EPO independent inventor variable in the regression in order to cover all possibilities.

51 We are grateful to Markus Reitzig for suggesting inclusion of this and the next two variables. A detailed assessment of their usefulness for assessing the value of patent rights is given in Reitzig (2002). 
- A dummy for the presence of one or more U.S. twins. Once we control for other patent characteristics, the relative probability that a patent with a twin is opposed increases slightly, from minus 12 per cent to minus 9 per cent. This finding is puzzling and requires further analysis. We speculate that this result may once again reflect some interdependence between the issue by the USPTO of a patent and the perceived strength or quality of the "twin" EPO patent. The EPO "twins" of patents that are survive USPTO review may be viewed as stronger by potential opponents, and therefore are less likely to trigger an opposition. Obviously, this speculative interpretation requires additional analysis of the timing of filings and oppositions in the US and EPO systems.

In general the results from the regressions in columns (1) and (2) confirm the findings in Harhoff and Reitzig (2001) that variables positively correlated with the value of a patent increase the probability that the patent will be subject to opposition. It is suggestive that patents held by independent inventors are no more likely to be opposed than other patents, other things equal. If we do not control for patent characteristics, however, patents held by independent inventors are 11 per cent more likely to be opposed; the main reason seems to be that they are more likely to be biotechnology/pharmaceutical patents. This result may reflect the greater presence of European university inventions within the biotech/pharma patent class, ownership of many of which remains with the individual faculty member.

Column (3) presents our preferred specification. Eliminating the insignificant variables does not affect the remaining coefficient estimates substantially. Patents held by German and West European assignees are about 7-9 per cent more likely to be opposed than patents held by residents of other countries. We explored the identity of the opposers, finding that they are more likely to come from countries that share a language with Germany or are in close proximity to a country that does. This suggests that the opposition system is more heavily used by those who are familiar with the language and culture of the country in which it is operated. It is natural therefore that the opposed patents also come from nearby countries, either because the (potential) opposers are more informed about them, or simply because they are more likely to be in the same narrow line of business. On the other hand, this finding may be caused by the choice of designated states for patent coverage, with Germany being the most favored choice. Inventors and corporations in European countries for which patent protection is not sought will have lower incentives to challenge patents that are not valid in their home country.

Finally, in column (4), we add the following variables concerning any U.S. twins for these patents:

- Whether the patent has more than one U.S. twin, a variable that is insignificant.

- A set of dummies for the number of USPTO citations received by the patent in the first ten years of its life. One additional forward cite of this type raises opposition probability 1 per cent, with some diminishing returns at high citation levels. The slightly lower coefficient for US citations relative to EPO citations may reflect the fact that USPTO patents have many more citations per patent than EPO patents. Although the EPO citation variables fall slightly in the presence of USPTO citation variables, both enter the equation significantly.

- A set of dummies for the number of claims in the U. S. patent (1-5, 6-9, 10, 11-15, more than 15). Unlike citations, these variables are not significant in the presence of the dummy variable for the number of claims in the EPO patent application. When we exclude the dummies for EPO claims, the dummies for the U.S. claims become slightly significant and 
negative. This result may well reflect the difficulty, noted earlier, of interpreting the meaning of the number of claims in a patent.

- Whether the U.S. application date was prior to the EPO application date. This reduces the probability of opposition by about 4 per cent, possibly reflecting the fact that more of the value of these patents relies on their exploitation in the U.S. market, making opposition in Europe less important. But the finding also is consistent with the "signaling" interpretation of U.S. patent issue that was noted earlier.

- Whether the USPTO coded the inventor as an independent inventor. This increases the probability by about 8 per cent, but the coefficient is insignificant. Measuring this more accurately is of some concern, given the reluctance of the US independent inventor community to embrace an opposition system. ${ }^{52}$ Controlling for grant year and nothing else, the raw difference in probability is 9.4 per cent with a standard error of 4.8 per cent.

The set of variables that describe the U.S. twin are jointly significant, with a $\chi^{2}(11)=42.6$. Adding them has little effect on the other coefficients, beyond a reduction in the size of the coefficient for the "U.S. twin" dummy to minus 14 per cent.

\subsection{Opposition Outcomes}

The outcomes of the oppositions for our sample are shown in Table 5. The category "opposition closed" refers to cases in which the patentholders do not renew patent protection after the opposition has been filed, which causes the patent to lapse into the public domain. Thus, these cases will mostly reflect a successful challenge of the patent's validity. Two facts are particularly striking: first, oppositions against patents with U.S. equivalents are more likely to be rejected. This may be due to the fact that patents from non-European applicants are selected carefully for patenting in Europe and are therefore more robust against the opposition challenge. It is also consistent with the argument that USPTO review does have a "quality-enhancing" effect on the issued patent. This result may also be a plausible explanation for the previously discussed negative impact of the "twin status" variable on the likelihood of opposition.

Second, the probability of outright revocation of a patent subjected to opposition is much higher than for re-examination: a total of 35.1 percent of the patents are revoked, not counting the opposition cases that are closed because the patent lapses (recall that only $9-11 \%$ of re-examined US patents are revoked in full). Presumably, these results reflect the wider grounds allowed for opposition and the presence of a third party in the opposition process.

Table 6 explores the relationship between patent characteristics and outcomes using a simple logit model of the following form:

$$
P_{j}=\operatorname{Pr}\left(\text { outcome } j \mid X_{i}\right)=\exp \left(X_{i} \beta_{j}\right) / \operatorname{Lexp}\left(X_{i} \beta_{k}\right)
$$

52 As we indicated earlier, there are many cases for which the U.S. variable is coded as unassigned that are currently (and perhaps, erroneously) included in the independent inventor class. In EPO applications, the listing of the applicant and of the inventors is compulsory. 
Where $j=$ outcome of the opposition (still pending, rejected, amended, closed, or revoked) and $X_{i}$ are various characteristics of the ith patent. In Table 6 we show the change in probability of each outcome type induced by a one-unit change in the right hand side dummy variable, holding all other variables constant:

$$
\Delta P_{j}\left(\Delta X_{i}^{l}=1\right)=P_{j}\left[\beta_{j}^{l}-\Sigma \beta_{k}^{l} \exp \left(X_{i} \beta_{k}\right) / \Sigma \exp \left(X_{i} \beta_{k}\right)\right]
$$

where $l$ indexes the right hand side variables. All effects are measured relative to the opposition pending outcome, so the rows in Table 6 sum to zero.

The results in Table 6 support the following conclusions:

1. Oppositions to patents with more citations or wider European coverage, or where there are multiple oppositions or multiple U.S. twins, tend to take longer to resolve.

2. Oppositions to biotech/pharma patents and/or highly cited patents, or where there are many claims, tend to result in amendment rather than a simple yes or no decision. Amendment is less likely when there are multiple oppositions or the inventor is an individual. More important patents or patents in relatively new, dynamic areas of inventive activity appear on this evidence to be more likely to be amended rather than revoked in an opposition.

3. Amendment is also more likely when an accelerated examination was requested for the patent. Recall that accelerated examinations are associated with a 25 percent higher probability of opposition in the first place. The two facts together suggest that these patents are in relatively new areas that are characterized by higher uncertainty about the technology, prior art, novelty, etc.

4. Revocation is more likely when there are multiple oppositions or few claims and substantially less likely when the patent is in the biotech/pharma area, when the patent is heavily cited by subsequent patents, when an accelerated search was requested, or when there are US twins. 


\section{CONCLUSIONS AND FURTHER QUESTIONS}

The determinants and characteristics of patent-challenge procedures are an important issue in any assessment of the U.S. or other industrial economies' intellectual property systems. In a "knowledge-based" economy, intellectual property systems are constantly challenged by the advance of technology, a process that among other things creates new artifacts to which the necessarily backward-looking patent system must respond. A "knowledge-based" economy also is one in which the high political salience of national and global intellectual property systems means that they are the focus of political lobbying to strengthen, adapt, or weaken specific features of intellectual property regulation, administration, and law in order to favor particular interests. Both of these forces have been at work within the US intellectual property system during the past quarter-century, a period of significant strengthening of patentholder rights has triggered a debate over the appropriate level and limits of such rights. Moreover, this debate has important trans-Atlantic and global echoes and analogues.

This paper has explored one dimension of the operations of the post-issue systems for challenging patent validity in the US and European intellectual property systems. The analysis presented here is preliminary and many issues remain open for further research. One of the most important gaps in our current data is the lack at present of data on rates of litigation for US patents that are re-examined and EPO patents (and their US "twins") that are opposed. The lack of these data prevents us from examining whether the use of oppositions results in lower rates of litigation, lowering costs and resolving uncertainty more rapidly. Any such conclusion requires that we extend the analysis to incorporate post-challenge litigation, which we hope to do in future research.

Nonetheless, the analysis in this paper (which itself needs to be extended to cover a broader array of patent classes and to incorporate the length and costs of litigation in the United States and Europe) highlights several interesting features of the patent-challenge systems of the US and EPO systems. First, the US re-examination procedure differs dramatically from the EPO opposition procedure in virtually all of its features. Perhaps the most significant of these contrasts is the identity of the party requesting a re-examination, which our data indicate is the patent owner in more than $40 \%$ of the cases. This characteristic of re-examination hardly qualifies it as the sort of adversarial procedure that EPO oppositions represent. With this fact in mind, comparisons of US re-examinations and EPO opposition proceedings must be treated with great caution.

Keeping in mind the significant differences between the re-examination and opposition processes, our comparative analysis suggests that EPO oppositions do not resolve validity challenges more quickly than the USPTO re-examination proceedings. In other words (and keeping in mind the incomplete nature of our data), for any given patent the EPO opposition process does not resolve uncertainties over the quality and breadth of patents more rapidly than the re-examination process. Indeed, opposition proceedings in some cases (and almost certainly, in important, complex cases with numerous opponents, appeals, etc.) may well take as much time to be resolved as litigation in the US system. Nonetheless, the higher frequency of opposition (which is presumably due to the lower cost associated with opposition as compared to the cost of 
litigation in the US) within the EPO system is at least consistent with the hypothesis that the opposition process handles many more legal disputes over patent validity than are addressed by the U.S. re-examination process.

Our analysis also indicates that patent amendment, rather than revocation, is more likely for oppositions in relative new fields of inventive activity, for more "complex" patents, or for oppositions in which numerous opponents participate. Since we lack evidence on the extent to which oppositions are followed by litigation in the European patent system, we cannot determine whether the lack of any "speed advantage" for oppositions in resolving patent disputes quickly is offset by a reduction of litigation rates associated with oppositions. The EPO system may offer few advantages over the U.S. system for post-issue patent challenges, but we cannot address this issue without analyzing litigation data for both the U.S. and European systems Any comprehensive assessment of the social costs and benefits of the two challenge systems requires that we consider both the "patent office" processes of post-grant challenge (opposition or reexamination) and litigation.

The analysis of EPO oppositions and USPTO re-examinations also indicates that more "valuable" or technologically important patents, based on the usual indicators of such characteristics, are more likely to trigger challenges. This conclusion is consistent with prior research, and if the private and social values of patent rights are correlated, higher levels of scrutiny for more important or valuable patents are welfare-enhancing. Misspecifications of the claims or other characteristics of important patents are likely to produce relatively large welfare losses, e.g., deviations from an optimal trade-off between market power allocated to the patent owner and incentives for R\&D (Harhoff and Reitzig 2001).

Our analysis of "twin patents" also suggests a complex interdependence between the probability of an EPO challenge and the issuance of a US "twin" patent. This interdependence must be explored further, but at least some evidence is consistent with the interpretation that "twin status" reflects selection issues that we have not addressed in this paper. There also appear to be some interesting issues of the timing of applications and issue of USPTO and EPO patents within these data, and we intend to analyze these issues in greater detail. The existence of such interdependence is hardly surprising in an integrated global economy, but these linkages have received little scrutiny from scholars of intellectual property policy.

The heading for this section thus is used advisedly, since we have raised as many questions as conclusions in this analysis. But this highlights the richness of the agenda for further research. 


\section{REFERENCES}

American Intellectual Property Law Association, 1999. "Report of Economic Survey," Washington, D.C.

Arora, A., 1997. "Licensing tacit knowledge: Intellectual Property Rights and the Market for Know-how," Economics of Innovation and New Technology 4: 41-59.

Arrow, K., 1962. "Economic Welfare and the Allocation of Resources for Invention," in The Rate and Direction of Inventive Activity: Economic and Social Factors. Princeton: Princeton University.

Baron, David P. "The nonmarket strategy system." Sloan Management Review, Fall 1995, 37(1): 73-85.

Barton, J.H. 2000. "Reforming the Patent System," Science 287: 1933-1934.

Bebchuk, L., 1984. "Litigation and Settlement under Imperfect Information," 15 Rand Journal of Economics 404.

Coase, R.H., 1960, "The Problem of Social Cost", Journal of Law and Economics 1-44

Cohen, W., R. Nelson, and J. Walsh. "Appropriability Conditions and Why Firms Patent and Why They Do Not in the American Manufacturing Sector," OECD working paper, 1996.

Cooter, R., and D. Rubinfeld. "Economic Analysis of Legal Disputes and their Resolution," Journal of Economic Literature, 27: 1067-97.

Courts Grant Them Preclusive Effect?", Journal of the Patent \& Trademark Office Society 125: 127-35.

Gable, R.L., and M. Montague, 2001. "Strategies to Defer Costs of Patenting: Use Provisional PCT Applications," New York Law Journal, March 5.

Hall, Bronwyn H., and Rosemarie Ham Ziedonis. 2001. "The Patent Paradox Revisited: An Empirical Study of Patenting in the U.S. Semiconductor Industry, 1979-1995," Rand Journal of Economics 32: 101-128.

Harhoff, Dietmar, and Markus Reitzig. 2001. "Determinants of Opposition against EPO Patent Grants The Case of Biotechnology and Pharmaceuticals." Muenchen: Ludwig-Maximilians-Universitaet. Photocopied.

Heller, Michael A., and Rebecca S. Eisenberg. 1998. "Can Patents Deter Innovation? The Anticommons in Biomedical Research," Science 698, May 1.

Hunt, Robert M. 2001. "You Can Patent That? Are Patents on Computer Programs and Business Methods Good for the New Economy?” Philadelphia Federal Reserve Bank Business Review, Spring.

James, Barry. 2001. “Agreeing on Little, EU Leaders Muddle Ahead," International Herald Tribune, March 26.

Kortum, S. and J. Lerner, "Stronger Patent Protection or Technological Revolution: What is behind the Recend Surge in Patenting?" NBER Working paper 6204.

Lanjouw, J. and J. Lerner, 1996. "Preliminary Injunctive Relief: Theory and Evidence from Patent Litigation," NBER working paper 5689, July.

Lanjouw, J. and J. Lerner, 1997. "The Enforcement of Intellectual Property Rights," NBER working paper 6296, December.

Lanjouw, J. and M. Schankerman, 2000. "Characteristics of Patent Litigation: A Window on Competition," working paper, March. 
Levin, R., A. Klevorick, R. Nelson, and S. Winter, 1987. "Appropriating the Returns from Industrial Research and Development" Brookings Papers on Economic Activity: 783-820.

Magrab, E. Brendan, 1993. "Patent Validity Determinations of the ITC: Should U.S. District Grant Them Preclusive Effect?," 75 Journal of the Patent \& Trademark Office Society 125, 127-35.

Merges, R. P., 1997. Patent Law and Policy. Charlottesville: Michie.

Merges, R., P. Menell, M. Lemley, and T. Jorde, 1997. Intellectual Property in the New Technological Age. New York: Aspen.

Merges, Robert P. 1999. “As Many as Six Impossible Patents Before Breakfast: Property Rights for Business Concepts and Patent System Reform," Berkeley High Technology Law Journal_14: 577615.

Meyer, M. (1999). "Does science push technology? Patents citing scientific literature," Research Policy, Vol. 29, No. 3, March 2000, pp. 409-434.

Michel, J. and B. Bettels, 2001. "Patent citation analysis - a closer look at the basic input data from patent research reports," Scientometrics 51, 181-201.

Michel, J. und B. Bettels (2001). "Patent citation analysis - A closer look at the basic input data from patent search reports", Scientometrics, Vol. 51, No. 1 (2001) 185-201.

Mowery, D., 1999. “The Computer Software Industry,” in D. Mowery and R. Nelson, eds., The Sources of Industrial Leadership. Cambridge: Cambridge University Press.

Mowery, D.C., R.R. Nelson, B.N. Sampat, and A.A. Ziedonis, 2001. "The Growth of Patenting and Licensing by U.S. Universities: An Assessment of the Effects of the Bayh-Dole Act of 1980," Research Policy 30: 99-119.

Nickerson, J., 1996. "Strategic Objectives Supported by Licensing." Technology Licensing: Corporate Strategies for Maximizing Value. New York: Wiley.

Nordhaus, W., 1969. Invention, Growth, and Welfare: A Theoretical Treatment of Technological Change. Cambridge, Mass.: MIT Press.

P'ng, I., 1983. "Strategic Behaviour in Suit, Settlement, and Trial," 14 Bell Journal of Economics 539.

Priest G. and B. Klein, 1984. "The Selection of Disputes for Litigation," 8 Journal of Legal Studies 1.

Quillen, Cecil D., Jr. 2001. "The Patent System: Is it Broke? And Who Can Fix It, If It Is?," Presentation to the Spring Meeting of the U. S. Association of General Counsels," May 12.

Reitzig, Markus. 2002. "Die Bewertung von Patentrechten - eine Analyse aus betriebswirtschaftlicher Sicht," Muenchen: Ludwig-Maximilians-Universitaet. Doctoral Thesis.

Scherer, F.M, 1965. "Corporate Inventive Output, Profits, and Growth," 73(3) The Journal of Political Economy 290.

Schmoch, U. (1993). "Tracing the knowledge transfer from science to technology as reflected in patent indicators," Scientometrics, Vol. 26, No. 1, pp. 193-211.

Somaya, D., 2000. "My Strategy Says: 'See you in Court!' Strategic Determinants of Patent Litigation Settlement Decisions in Computers and Research Medicines," working paper, March.

Speranza, R. \& J. Goldman, 1987. "Reexamination--the Patent Challenger's View." 15 American Intellectual Property Law Association Quarterly Journal 85.

Stauder, D. (1989). Patent- und Gebrauchsmusterverletzungsklagen in der Bundesrepublik Deutschland, Großbritannien, Frankreich und Italien. Schriftenreihe zum Gewerblichen Rechtsschutz (Vol. 89), 
Max-Planck-Institut für ausländisches und internationales Patent-, Urheber- und Wettbewerbsrecht. Köln.

Stauder, Dieter (1996). "Aspekte der Durchsetzung gewerblicher Schutzrechte: Fachkundiger Richter, schnelles Verfahren und europaweites Verletzungsgebot," in: Beier, A. (Ed.): Aktuelle Herausforderungen des geistigen Eigentums."

Stauder, Dieter, P. von Rospatt, M. von Rospatt (1999). "Protection transfrontalière des brevets europeéns," Revue Internationals de Droit Economique, 1, pp. 119-133.

Teece, D., 1986. "Profiting from Technological Innovation: Implications for Integration, Collaboration, Licensing, and Public Policy." 15 Research Policy 285. 


\section{APPENDIX}

\section{Liposome Corporation - Patent No. 4,880,635 (EPO Publ. No. 190,315)}

In July 1985, the Liposome Corporation (LC) submitted an application in the US Patent and Trademark office for a patent on their "Dehydrated liposome" innovation, enabling the use of liposomes--fatty bubbles--that can carry drugs and cause the medication to concentrate at the site of an infection. Within a month, the firm had submitted an application at the European Patent Office to secure patent rights in Europe. The European application was published in August 1986, based upon Liposome's claimed international priority date of August 1984.

After pending in the Patent Office for 4 years and 4 months, the US patent issued on November 14, 1989 (patent number 4,880,635), with 9 claims. During the next several years, LC began distributing its drug Abelcet, an anti-fungal treatment used for AIDS-related infections and based on its '635 patent. Rival Nexstar, Incorporated (formerly known as Vestar) developed a competing liposomal drug AmBisome, prompting LC to notify Nexstar that it believed the anti-fungal AmBisome infringed its patent. On May 17, 1993, Nexstar sued LC in the Federal District Court in Delaware, seeking a declaration that the '635 patent was invalid, and LC counterclaimed, charging AmBisome with infringement.

Presented with new prior art that created some likelihood that Nexstar would prevail in court, LC decided on July 13, 1993 to request an "owner-initiated" reexamination on its '635 patent, thus gaining for itself an ex parte proceeding with the US Patent Office to determine the impact of the new prior art. This reexamination enabled LC to re-enter negotiations with the Patent Office over the patent's claims. If the USPTO upheld the suspect claims, the presumption of validity of the ' 635 before the court would be strengthened.

LC was awarded its equivalent European Patent, EP 190315, on October 17, 1993. LC designated Austria, Belgium, Switzerland, Germany, France, Great Britain, Italy, Liechtenstein, Luxembourg, and Sweden as states in which it intended to patent. Nexstar opposed the LC's EPO patent on April 6, 1994, and was joined in opposition by Daiichi Pharmaceutical Company on September 21. On December 21, 1994, the Delaware District Court found that LC's patent was invalid and that Nexstar's product was not infringing. As of this date, no decision has been delivered in the Nextar / Daiichi opposition proceedings, thus suggesting the cases are essentially closed.

Legal maneuvers kept the US litigation alive through 1995 and, on June 7, 1996 LC announced that it had been "upheld" by the US Patent Office in its reexamination. Company officials declared that the patent's "presumption of validity [was] enhanced" and threatened Nexstar with an injunction to prevent it from selling AmBisome. LC shares were up 3.4\% on the news that day, while Nexstar's dropped 21.5\%. (Marc Monseau, "Patent Office upholds Liposome patent," Denver Rocky Mountain News, June 7, 1996).

The news also appears to have scuttled Nexstar's plans for a \$60 million new share offering in June 1996 that would finance the firm's acquisition of new drugs, marketing its newest product, and research \& development. (David Algeo, "Nexstar may kill offering," The Denver Post, D:1, June 8, 1996). Nexstar officer said that LC's announcement of the outcome of its patent re-examation had harmed the firm (Jesse Eisinger, "Patent ruling may hamper Nexstar offering," Denver Rocky Mountain News, 5B, June 11, 1996).

The USPTO certificate on the reexamination of the ' 635 patent finally issued on July 2, 1996, and the facts did not entirely support LC's press releases of a month earlier. In reality, B1 Certification 2,937 stated that 3 claims had been cancelled, 6 claims had been amended, and 19 new claims were added. 
Nexstar returned to federal court in May of 1997, claiming that LC had purposefully misrepresented the reexamination results to gain advantage and injure Nexstar, and argued that the ' 635 patent was invalid.

EP190315 was opposed at the EPO on Feb. 1, 1994 by Nexstar and Daiichi Pharmaceutical. The case is still pending on appeal, and we do not know the preliminary outcome. It is probable, based on the events discussed immediately below, that they are not waiting for the final outcome and the case is essentially closed.

The two competitors ultimately reached a settlement in their U.S. court case on August 11, 1997, jointly stipulating to a dismissal. In the settlement, LC granted Nexstar immunity from future suits in connection with its worldwide manufacture and marketing of AmBisome. The firms agreed to grant reciprocal options to take licenses to the other's patented technologies, while Nexstar agreed to unspecified payments to LC. The following day, Nexstar's AmBisome was approved by the Food and Drug Administration for marketing in the United States.

\section{Ortho Pharmaceuticals - U. S. Patent 4,363,799 (EPO Publ. No. 17381)}

By the early 1980s, monoclonal antibodies had been recognized as a remarkable advance in medical science. The discovery, which allows the identification of so-called $\mathrm{T}$ cell subsets of lymphocytes, a type of white blood cell, showed promise for enabling advancements in the treatment of infectious disease, cancer, infertility, autoimmune disorders, heart disease, and other maladies. In 1984, sales of diagnostics and therapies using the technique grossed US \$500 million, with projections of annual sales of US \$2 billion by 1990 (Lawrence Altman, "A Discovery and its Impact: Nine Years of Excitement," NYT, C:3, Oct. 16, 1984). The founders of the technique were awarded the 1984 Nobel Prize in Medicine, signaling its path breaking nature.

On March 20, 1979, the Ortho Pharmaceutical Corporation applied for a United States patent on its invention entitled "Monoclonal antibody to human T cells, and methods for preparing same." On March 19, 1980, presumably taking advantage of the 1-year application window allowed in the EPO, Ortho applied for its equivalent European patent, application number EP1980030082, using the US application date as its priority date. Based on the application's March 1979 international priority date, the EPO published the application on October 15 1980, signaling the existence of the pending patent. Ortho designated its European states of interest on that date as Austria, Belgium, Switzerland, Germany, France, Great Britain, Holland, Italy, and Sweden.

On December 14, 1982, after some 2 years and 9 months pending in the US Patent Office, the US patent issued (number 4,363,799), with 11 claims. Approximately two years later, on September 20, 1984, Ortho filed a complaint alleging patent infringement against Becton Dickinson Monoclonal Center, Inc. in the Federal District Court in Wilmington, Delaware. The complaint also covered 12 other patents owned by Ortho. Within 10 months, the European equivalent patent (No. 17381) issued, on July 10, 1985.

During 1986, legal maneuvering on both sides of the Atlantic tested the validity of the Ortho patent. On June 4, 1986, an EPO opposition was filed by Behringwerke AG and Sandoz AG. Within a week, on June 11, a second opposition was filed by Becton, Dickinson \& Company and by Boehringer Mannheim GMBH. On July 24, 1986, Ortho's US infringement action against Becton Dickinson, an opponent to Ortho's EPO patent, was transferred to the Federal District Court in Northern California. On September 26, Ortho again asserted its patent in an infringement action against Coulter Corporation and Coulter Electronics Corporation in the Southern District of Florida.

By October 3, 1986, Ortho and Becton Dickinson had settled their California litigation. Each party stipulated to a voluntary dismissal of the case and the Court announcing that the parties had "resolved 
their differences." But the EPO opposition proceedings continued, and after the two pending oppositions were consolidated, the EPO patent was revoked on October 17, 1986. Ortho immediately appealed the adverse decision to the EPO, but the appeal was finally rejected on January 8, 1991, five years after settlement of the firm's infringement suit against one of the EPO patent opponents.

Ortho's suit against Coulter Corporation and Coulter Electronics Corporation in the Southern District of Florida was finally settled in November, 1993, with a consent judgment and a dismissal. Ortho's US patent remains in force but has not been asserted in court since. The patent number is not withdrawn, although the patent is close to expiration. 
Table 1

Lags between Application, Grant, Challenge, and Final Outcome

\begin{tabular}{|l|c|c|c|c|c|c|}
\hline & \multicolumn{3}{|c|}{ EPO $^{*}$} & \multicolumn{3}{c|}{ USPTO $^{* *}$} \\
\cline { 2 - 7 } & \# Obs. & Median & IQ Range & \# Obs. & Median & IQ Range \\
\hline $\begin{array}{l}\text { Lag btwn application \& } \\
\text { grant }\end{array}$ & 2022 & 4.78 & 2.15 & 3208 & 1.72 & 0.90 \\
$\begin{array}{l}\text { Lag btwn grant \& first } \\
\text { challenge }\end{array}$ & 2027 & 0.75 & 0.01 & 3208 & 2.82 & 4.92 \\
$\begin{array}{l}\text { Lag btwn first challenge } \\
\text { \& final outcome }\end{array}$ & 1526 & 2.73 & 2.34 & 3208 & 1.28 & 0.91 \\
\hline Total lag & 1519 & 8.35 & 3.24 & 3208 & 6.36 & 5.50 \\
\hline
\end{tabular}

Pre-1991 Applications Only

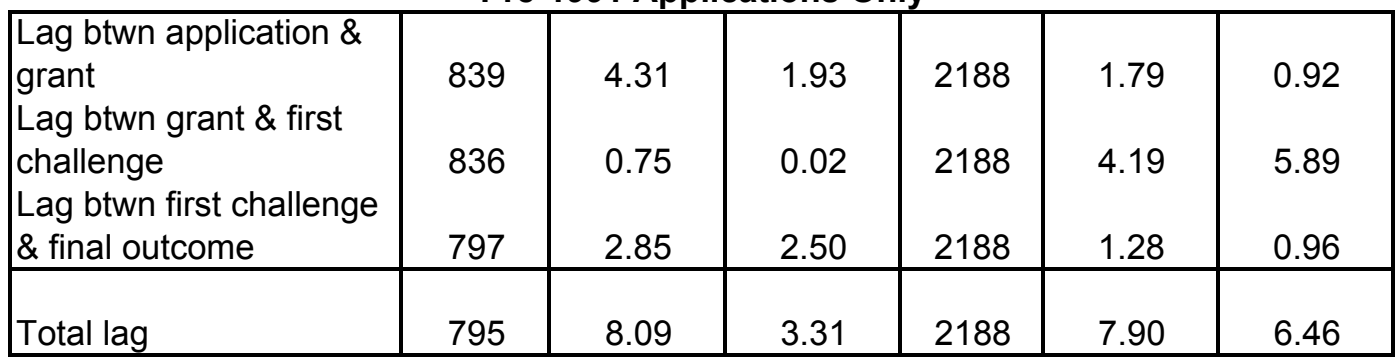

*These numbers are for our sample of opposed patents only; only the first opposition is used.

**These numbers are for all re-examined patents (requests 1974-2000; duplicates removed).

Neither set have not been adjusted for truncation. 
Table 2

Probability of a Re-examination Request

Binary probit estimation (23,444 observations; 3,078 re-exams)

\begin{tabular}{|c|c|c|c|c|c|c|c|c|c|c|}
\hline & \multicolumn{5}{|c|}{ All Observations $(23,444 ; 3,078$ re-exams $)$} & \multicolumn{5}{|c|}{ Patents granted before 1991 (12,160; 2,058 re-exams) } \\
\hline & $\begin{array}{c}\text { No. of re- } \\
\text { exams\# }\end{array}$ & Dprob/dx+ & Std. Error & Dprob/dx+ & Std. Error & & Dprob/dx+ & Std. Error & Dprob/dx+ & Std. Error \\
\hline $\begin{array}{l}\text { Bio/pharma } \\
\text { Semiconductor/hardware } \\
\text { Software }\end{array}$ & $\begin{array}{c}26 \\
183 \\
56 \\
\end{array}$ & $\begin{array}{l}-0.0175 \\
-0.0271 \\
-0.0667 \\
\end{array}$ & $\begin{array}{l}0.0169 \\
0.0070 \\
0.0069\end{array}$ & $\begin{array}{l}-0.0216 \\
-0.0215 \\
-0.0645 \\
\end{array}$ & $\begin{array}{l}0.0171 \\
0.0070 \\
0.0063\end{array}$ & $\begin{array}{c}14 \\
126 \\
31 \\
\end{array}$ & $\begin{array}{l}-0.0229 \\
-0.0032 \\
-0.0759\end{array}$ & $\begin{array}{l}0.0367 \\
0.0143 \\
\mathbf{0 . 0 1 6 0} \\
\end{array}$ & $\begin{array}{r}-0.0335 \\
0.0030 \\
-\mathbf{0 . 0 7 8 2} \\
\end{array}$ & $\begin{array}{l}0.0337 \\
0.0146 \\
\mathbf{0 . 0 1 5 2} \\
\end{array}$ \\
\hline $\begin{array}{l}\text { \#cites }(10 y r)=1 \text { or } 2 \\
\text { \#cites }(10 y r)=3 \text { to } 10 \\
\text { \#cites }(10 y r)=10 \text { to } 20 \\
\text { \#cites }(10 y r)>20\end{array}$ & $\begin{array}{c}481 \\
1240 \\
668 \\
469 \\
\end{array}$ & $\begin{array}{l}0.0550 \\
0.1417 \\
0.3468 \\
0.5745 \\
\end{array}$ & $\begin{array}{l}0.0086 \\
0.0091 \\
0.0168 \\
0.0197 \\
\end{array}$ & $\begin{array}{l}0.0418 \\
0.1180 \\
0.2935 \\
0.5005 \\
\end{array}$ & $\begin{array}{l}0.0082 \\
0.0086 \\
0.0165 \\
0.0216 \\
\end{array}$ & $\begin{array}{l}295 \\
842 \\
511 \\
333 \\
\end{array}$ & $\begin{array}{l}0.0927 \\
0.1913 \\
0.4488 \\
0.6563 \\
\end{array}$ & $\begin{array}{l}0.0161 \\
0.0143 \\
0.0228 \\
0.0218 \\
\end{array}$ & $\begin{array}{l}0.0846 \\
0.1735 \\
0.4089 \\
0.6017 \\
\end{array}$ & $\begin{array}{l}0.0158 \\
0.0142 \\
0.0240 \\
0.0250 \\
\end{array}$ \\
\hline \begin{tabular}{|l} 
\#claims $=6$ to 9 \\
\#claims $=10$ \\
\#claims $=11$ to 15 \\
\#claims $>15$ \\
\#claims missing
\end{tabular} & $\begin{array}{c}613 \\
166 \\
602 \\
1228 \\
10\end{array}$ & & & $\begin{array}{r}0.0167 \\
0.0215 \\
0.0385 \\
0.0593 \\
-0.0672\end{array}$ & $\begin{array}{l}0.0064 \\
0.0105 \\
0.0074 \\
0.0069 \\
0.0104\end{array}$ & $\begin{array}{c}439 \\
120 \\
403 \\
774 \\
2\end{array}$ & & & $\begin{array}{l}0.0278 \\
0.0384 \\
0.0565 \\
0.1009 \\
0.1172\end{array}$ & $\begin{array}{l}0.0102 \\
0.0171 \\
0.0117 \\
0.0116 \\
0.1607\end{array}$ \\
\hline \begin{tabular}{||l} 
Individual assignee \\
Government assignee \\
U.S. inventor \\
Non-European developed \\
country patent* \\
Chi-squared and p-val for \\
regional dummies $(\mathrm{df}=6)$
\end{tabular} & $\begin{array}{c}522 \\
14 \\
2337 \\
\\
102\end{array}$ & $\begin{array}{c}0.0031 \\
-0.0798\end{array}$ & $\begin{array}{l}0.0053 \\
\mathbf{0 . 0 0 8 0}\end{array}$ & $\begin{array}{r}-0.0063 \\
-0.0756 \\
0.0540 \\
0.0815 \\
49.48 \\
\end{array}$ & $\begin{array}{l}0.0490 \\
0.0071 \\
0.0040 \\
0.0172 \\
0.0000\end{array}$ & $\begin{array}{c}351 \\
11 \\
1566 \\
\\
56\end{array}$ & $\begin{array}{r}0.0052 \\
-0.1100\end{array}$ & $\begin{array}{l}0.0085 \\
\mathbf{0 . 0 1 2 7}\end{array}$ & $\begin{array}{r}-0.0042 \\
-0.1080 \\
0.0616 \\
0.0607 \\
26.07\end{array}$ & $\begin{array}{l}0.0083 \\
0.0121 \\
0.0068 \\
0.0259 \\
0.0004\end{array}$ \\
\hline $\begin{array}{l}\text { Pseudo R-squared } \\
\text { Log likelihood } \\
\text { Chi-squared (df)++ }\end{array}$ & & $\begin{array}{r}0.1 \\
-792 \\
1595.98 \\
\end{array}$ & $\begin{array}{ll}31 & \\
.01 & \\
& 9\end{array}$ & $\begin{array}{r}0.1 \\
-773 \\
1965.96\end{array}$ & 02 & & $\begin{array}{r}0.1 \\
-488 \\
1228.77\end{array}$ & $\begin{array}{ll}17 & \\
\\
1.43\end{array}$ & $\begin{array}{r}0.1 \\
-477 \\
1434.03\end{array}$ & $\begin{array}{ll}36 & \\
3.81 & \\
& 16\end{array}$ \\
\hline
\end{tabular}

The left-out category is a corporate-owned patent granted in 1975/76 with fewer than 6 claims and no citations within 10 years after grant.

\#The number of re-exams that have the characteristic described.

+ This is the increase in probability for a unit change to the dummy (all variables are dummy variables).

++ Grant year dummies are included in all estimations; the null hypothesis is these dummies only.

*Australia, Canada, New Zealand, Israel

**Japan, Germany, Other Asia, Other W. Europe, E. Europe, Other 
Table 3

Reexamination outcomes, 1981-2000 (Patents granted 1975-1999)

All technologies**

\begin{tabular}{|c|c|c|c|c|c|c|c|}
\hline Claims & NOA $^{*}$ & Added & $\begin{array}{c}\text { with } \\
\text { Cancelled }\end{array}$ & Add\&Cancel & Totals & Share & $\begin{array}{c}\text { Share } \\
\text { with any }\end{array}$ \\
\hline Claims added & 145 & - & -- & -- & 145 & $4.6 \%$ & $33.9 \%$ \\
\hline Claims cancelled & 181 & 146 & -- & -- & 327 & $10.5 \%$ & $35.9 \%$ \\
\hline Claims amended & 466 & 371 & 397 & 399 & 1633 & $52.2 \%$ & $52.2 \%$ \\
\hline No change & 734 & -- & -- & -- & 734 & $23.5 \%$ & $30.7 \%$ \\
\hline Patent cancelled & 288 & -- & -- & -- & 288 & $9.2 \%$ & $9.2 \%$ \\
\hline Total & 1814 & 517 & 397 & 399 & 3127 & $100.0 \%$ & \\
\hline
\end{tabular}

Biotech/pharma and Semiconductors/computer hardware \& software***

\begin{tabular}{|l|c|ccc|c|c|c|}
\hline Claims & NOA $^{*}$ & Added & Cancelled & Add\&Cancel & Totals & Share & $\begin{array}{c}\text { Share } \\
\text { with any }\end{array}$ \\
\hline Claims added & 11 & -- & -- & -- & $\mathbf{1 1}$ & $\mathbf{4 . 2 \%}$ & $\mathbf{2 8 . 5 \%}$ \\
Claims cancelled & 19 & 4 & -- & -- & $\mathbf{2 3}$ & $\mathbf{8 . 7 \%}$ & $\mathbf{3 1 . 6 \%}$ \\
Claims amended & 53 & 30 & 30 & 30 & $\mathbf{1 4 3}$ & $\mathbf{5 4 . 4 \%}$ & $\mathbf{5 4 . 4 \%}$ \\
No change & 56 & -- & -- & -- & $\mathbf{5 6}$ & $\mathbf{2 1 . 3 \%}$ & $\mathbf{2 3 . 8 \%}$ \\
Patent cancelled & 30 & -- & -- & -- & $\mathbf{3 0}$ & $\mathbf{1 1 . 4 \%}$ & $\mathbf{1 1 . 4 \%}$ \\
\hline Total & $\mathbf{1 6 9}$ & $\mathbf{3 4}$ & $\mathbf{3 0}$ & $\mathbf{3 0}$ & $\mathbf{2 6 3}$ & $\mathbf{1 0 0 . 0 \%}$ & \\
\hline
\end{tabular}

${ }^{*} \mathrm{NOA}=$ no other action noted

${ }^{* *}$ Of 3208 records, $3127(97.5 \%)$ have outcome notations

${ }^{* * *}$ Of 268 records, $263(98.1 \%)$ have outcome notations.

Each re-exam appears only once.

Numbers in the last column do not add to $100 \%$ because some re-exams yield multiple outcomes.

In the cases where there is more than one re-examination request, only the final outcome is shown.

There are 306 multiple requests; only the final outcome is included in this table. 
Table 4 (part 1)

Probability of an Opposition

Binary probit estimation (4868 observations; 2021 opposed)

\begin{tabular}{|c|c|c|c|c|c|c|c|}
\hline 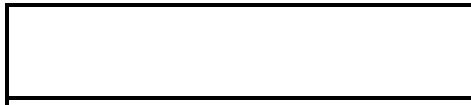 & $\begin{array}{l}\text { No. of obs } \\
\text { equal to } 1\end{array}$ & \multicolumn{3}{|c|}{ (1) } & Dprob/dx+ & $\begin{array}{l}\text { (2) } \\
\text { Std. Erro }\end{array}$ & \\
\hline \multicolumn{8}{|l|}{ EPO characteristics } \\
\hline Biotech/pharma technology & 2,157 & 0.159 & 0.020 & *** & \multicolumn{3}{|c|}{ Full 14 tech dummies++ } \\
\hline No. of forward EPO cites $=1$ & 974 & 0.060 & 0.022 & *** & 0.064 & 0.023 & *** \\
\hline No. of forward EPO cites $=2 / 5$ & 1,311 & 0.163 & 0.021 & *** & 0.173 & 0.021 & *** \\
\hline No. of forward EPO cites $=6 / 10$ & 258 & 0.229 & 0.035 & *** & 0.224 & 0.036 & *** \\
\hline No. of forward EPO cites $>10$ & 80 & 0.400 & 0.051 & *** & 0.418 & 0.050 & *** \\
\hline No. of designated states $6-10$ & 1,082 & 0.137 & 0.022 & *** & 0.128 & 0.023 & $\bar{*}^{* * *}$ \\
\hline No. of designated states $>10$ & 1,733 & 0.175 & 0.024 & $* * *$ & 0.169 & 0.025 & *** \\
\hline No. of EPO claims 6-9 & 1,192 & 0.015 & 0.024 & & 0.010 & 0.025 & \\
\hline No. of EPO claims $=10$ & 580 & 0.044 & 0.030 & & 0.022 & 0.030 & \\
\hline No. of EPO claims $11-15$ & 1,068 & 0.051 & 0.026 & $* *$ & 0.033 & 0.026 & \\
\hline No. of EPO claims >15 & 1,244 & 0.118 & 0.026 & *** & 0.105 & 0.026 & *** \\
\hline Independent inventor (EPO ass.) & 220 & 0.028 & 0.036 & & 0.016 & 0.036 & \\
\hline Accelerated search requested & 86 & -0.136 & 0.054 & ** & -0.140 & 0.054 & $\star *$ \\
\hline Accelerated exam requested & 140 & 0.243 & 0.045 & *** & 0.240 & 0.046 & *** \\
\hline PCT application & 937 & 0.122 & 0.023 & *** & 0.131 & 0.024 & *** \\
\hline \multicolumn{8}{|l|}{ Nationality of patentholder } \\
\hline U.S. & 1,642 & -0.012 & 0.049 & & 0.000 & 0.049 & \\
\hline Germany & 713 & 0.101 & 0.053 & * & 0.096 & 0.053 & * \\
\hline Other West European & 1,240 & 0.075 & 0.050 & & 0.072 & 0.050 & \\
\hline Japan & 1,154 & 0.042 & 0.051 & & 0.045 & 0.051 & \\
\hline Chi-squared (4) for region dummies & & \multicolumn{2}{|c|}{29.50} & $* * \star$ & \multicolumn{2}{|c|}{20.30} & *** \\
\hline Chi-squared (2) for US,JP & & \multicolumn{2}{|c|}{5.96} & * & \multicolumn{3}{|c|}{3.85} \\
\hline \multicolumn{8}{|l|}{ US Twin characteristics } \\
\hline US Twin exists & 2,893 & -0.089 & 0.016 & *** & -0.094 & 0.016 & *** \\
\hline More than one US twin & 95 & & & & & & \\
\hline No. of US forward cites $=1$ or 2 & 571 & & & & & & \\
\hline No. of US forward cites $=3 / 10$ & 1,327 & & & & & & \\
\hline No. of US forward cites $=10 / 20$ & 512 & & & & & & \\
\hline No. of US forward cites $>20$ & 271 & & & & & & \\
\hline No. of US claims 6-9 & 751 & & & & & & \\
\hline No. of US claims $=10$ & 157 & & & & & & \\
\hline No. of US claims $11-15$ & 555 & & & & & & \\
\hline No. of US claims > 15 & 846 & & & & & & \\
\hline US app. date prior to EPO & 1,495 & & & & & & \\
\hline Independent inventor (USPTO ass.) & 124 & & & & & & \\
\hline Log likelihood & & -286 & 4.89 & & -281 & 0.72 & \\
\hline Pseudo R-squared & & & & & & 48 & \\
\hline Chi-squared (df) & & 877.5 & (37) & & 977. & $(49)$ & \\
\hline
\end{tabular}

+ This is the increase in probability for a unit change to the dummy.

++ One of the dummies predicts opposition perfectly, so the increase in degrees of freedom is only $12=13-1$.

All equations include a complete set of 18 grant year dummies.

The left-out category is a corporate patent in semiconductor/software with number of states $<6$, number of claims $<6$, zero forward cites, and with holder from a country other than the "triad." 
Table 4 (part 2)

Probability of an Opposition

Binary probit estimation (4868 observations; 2021 opposed)

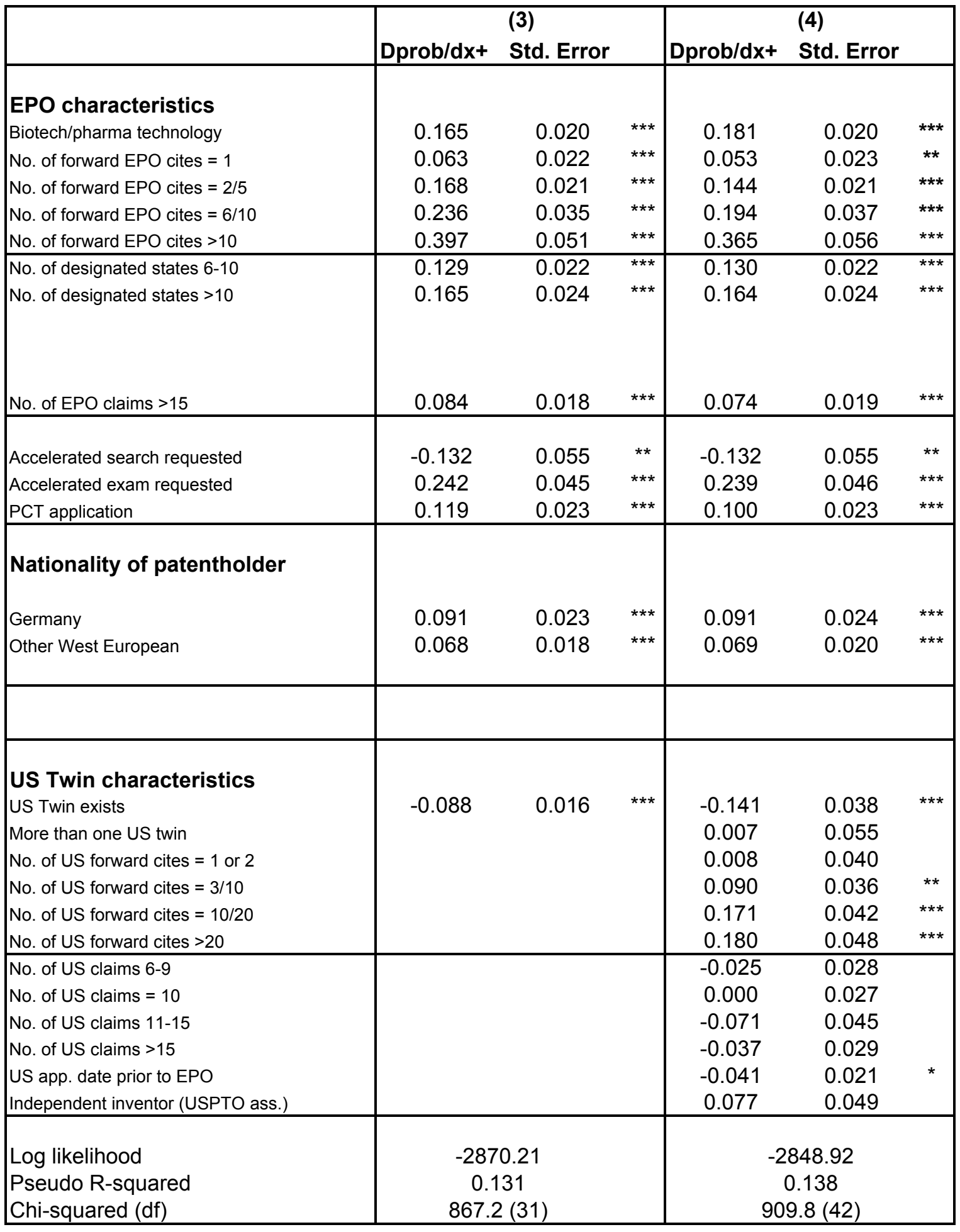

Chi-squared for US patent vars.

42.6

$11 * * *$ 
Table 5

Final Outcome of Oppositions

\begin{tabular}{|c|c|c|c|c|c|}
\hline & Total & $\begin{array}{l}\text { With US } \\
\text { Twin }\end{array}$ & $\begin{array}{c}\text { Percent with } \\
\text { US Twin }\end{array}$ & $\begin{array}{l}\text { Share of } \\
\text { outcomes }\end{array}$ & $\begin{array}{l}\text { With US } \\
\text { Twin }\end{array}$ \\
\hline $\begin{array}{l}\text { Opposition rejected } \\
\text { Opposition rejected on appeal } \\
\text { Opposition rejected - total }\end{array}$ & $\begin{array}{c}266 \\
85 \\
351 \\
\end{array}$ & $\begin{array}{c}173 \\
47 \\
220 \\
\end{array}$ & $\begin{array}{l}65.0 \% \\
55.3 \% \\
62.7 \% \\
\end{array}$ & $17.4 \%$ & $21.4 \%$ \\
\hline $\begin{array}{l}\text { Patent amended } \\
\text { Patent amended on appeal } \\
\text { Patent amended - total }\end{array}$ & $\begin{array}{l}355 \\
163 \\
\mathbf{5 1 8}\end{array}$ & $\begin{array}{c}207 \\
81 \\
288\end{array}$ & $\begin{array}{l}58.3 \% \\
49.7 \% \\
55.6 \%\end{array}$ & $25.6 \%$ & $28.0 \%$ \\
\hline $\begin{array}{l}\text { Patent revoked } \\
\text { Patent revoked on appeal } \\
\text { Patent revoked - total } \\
\end{array}$ & $\begin{array}{l}366 \\
184 \\
\mathbf{5 5 0}\end{array}$ & $\begin{array}{c}181 \\
92 \\
273\end{array}$ & $\begin{array}{l}49.5 \% \\
50.0 \% \\
49.6 \%\end{array}$ & $27.2 \%$ & $26.6 \%$ \\
\hline Opposition closed & 150 & 81 & $54.0 \%$ & $7.4 \%$ & $7.9 \%$ \\
\hline $\begin{array}{l}\text { Opposition case pending } \\
\text { Appeals case pending } \\
\text { Case pending - total }\end{array}$ & $\begin{array}{l}190 \\
262 \\
452\end{array}$ & $\begin{array}{c}72 \\
94 \\
166\end{array}$ & $\begin{array}{l}37.9 \% \\
35.9 \% \\
36.7 \%\end{array}$ & $22.4 \%$ & $16.1 \%$ \\
\hline Total & 2021 & 1028 & $50.9 \%$ & $100.0 \%$ & $100.0 \%$ \\
\hline
\end{tabular}

\section{Summary}

\begin{tabular}{|l|c|c|c|c|c|}
\hline & & \multicolumn{4}{|c|}{ Share of Outcomes } \\
\cline { 2 - 6 } Outcome & Total & Total & $\begin{array}{c}\text { Biotech/ } \\
\text { pharma }\end{array}$ & $\begin{array}{c}\text { Computer } \\
\text { hardware/so } \\
\text { ftware }\end{array}$ & $\begin{array}{c}\text { With Us } \\
\text { Twin }\end{array}$ \\
\hline Opposition rejected - total & 351 & $22.4 \%$ & $19.1 \%$ & $26.8 \%$ & $25.5 \%$ \\
Patent amended - total & 518 & $33.0 \%$ & $38.1 \%$ & $26.1 \%$ & $33.4 \%$ \\
Patent revoked - total & 550 & $35.1 \%$ & $31.5 \%$ & $40.0 \%$ & $31.7 \%$ \\
Opposition closed & 150 & $9.6 \%$ & $11.3 \%$ & $7.1 \%$ & $9.4 \%$ \\
Total with an outcome & $\mathbf{1 5 6 9}$ & $\mathbf{1 0 0 . 0 \%}$ & $\mathbf{1 0 0 . 0 \%}$ & $\mathbf{1 0 0 . 0 \%}$ & $\mathbf{1 0 0 . 0 \%}$ \\
\hline Opposition pending & 452 & $22.4 \%$ & $27.7 \%$ & $13.6 \%$ & $16.1 \%$ \\
Total & $\mathbf{2 0 2 1}$ & & & & \\
\hline
\end{tabular}


Table 6

Multinomial Logit for Opposition Outcomes

2,021 Observations

\begin{tabular}{|c|c|c|c|c|c|c|c|c|c|c|}
\hline & \multicolumn{5}{|c|}{ Change in Probability Going from Dummy=0 to Dummy=1 (\#obs.) } & \multicolumn{5}{|c|}{ Change in Probability Going from Dummy=0 to Dummy=1 (\#obs.) } \\
\hline & $\begin{array}{c}\text { Opposition } \\
\text { rejected (351) } \\
\end{array}$ & $\begin{array}{l}\text { Pending } \\
(452)\end{array}$ & $\begin{array}{c}\text { Patent } \\
\text { amended(518) } \\
\end{array}$ & $\begin{array}{l}\text { Opposition } \\
\text { closed (150) }\end{array}$ & $\begin{array}{c}\text { Patent revoked } \\
(550)\end{array}$ & $\begin{array}{c}\text { Opposition } \\
\text { rejected (351) }\end{array}$ & $\begin{array}{l}\text { Pending } \\
(452)\end{array}$ & $\begin{array}{c}\text { Patent } \\
\text { amended(518) } \\
\end{array}$ & $\begin{array}{l}\text { Opposition } \\
\text { closed (150) }\end{array}$ & \begin{tabular}{|c} 
Patent revoked \\
$(550)$
\end{tabular} \\
\hline Biotech/pharma & $-2.9 \%$ & $1.7 \%$ & $10.3 \%$ & $1.4 \%$ & $-10.5 \%$ & $-3.9 \%$ & $2.8 \%$ & $11.7 \%$ & $0.6 \%$ & $-11.2 \%$ \\
\hline EPO Citations $>10$ & $-15.5 \%$ & $14.1 \%$ & $11.3 \%$ & $4.7 \%$ & $-14.6 \%$ & $-14.6 \%$ & $12.6 \%$ & $11.1 \%$ & $3.9 \%$ & $-13.0 \%$ \\
\hline Designated states 6/10 & $-1.1 \%$ & $3.9 \%$ & $1.1 \%$ & $-1.0 \%$ & $-2.9 \%$ & & & & & \\
\hline Designated states $>10$ & $-0.2 \%$ & $8.2 \%$ & $-3.9 \%$ & $-0.5 \%$ & $-3.7 \%$ & $0.6 \%$ & $5.7 \%$ & $-5.0 \%$ & $0.4 \%$ & $-1.7 \%$ \\
\hline No. of EPO claims 6-9 & $-1.7 \%$ & $-3.9 \%$ & $7.4 \%$ & $-2.4 \%$ & $0.6 \%$ & & & & & \\
\hline No. of EPO claims $=10$ & $-5.1 \%$ & $-2.4 \%$ & $8.2 \%$ & $-5.5 \%$ & $4.8 \%$ & & & & & \\
\hline No. of EPO claims $11-15$ & $-2.3 \%$ & $-5.4 \%$ & $13.2 \%$ & $-4.4 \%$ & $-1.0 \%$ & $-0.2 \%$ & $-2.7 \%$ & $8.1 \%$ & $-2.2 \%$ & $-3.0 \%$ \\
\hline No. of EPO claims >15 & $-2.5 \%$ & $-1.0 \%$ & $13.5 \%$ & $-0.8 \%$ & $-9.2 \%$ & $-0.4 \%$ & $2.1 \%$ & $8.4 \%$ & $1.4 \%$ & $-11.5 \%$ \\
\hline Accelerated search requested & $4.5 \%$ & $0.8 \%$ & $3.7 \%$ & $1.8 \%$ & $-10.8 \%$ & & & & & \\
\hline Accelerated exam requested & $-5.4 \%$ & $5.2 \%$ & $7.3 \%$ & $-1.0 \%$ & $-6.2 \%$ & $-5.3 \%$ & $5.3 \%$ & $7.3 \%$ & $-0.7 \%$ & $-6.6 \%$ \\
\hline PCT filing & $-2.6 \%$ & $2.4 \%$ & $-0.2 \%$ & $1.3 \%$ & $-0.9 \%$ & & & & & \\
\hline US patentholder & $2.4 \%$ & $-0.2 \%$ & $2.0 \%$ & $-3.1 \%$ & $-1.1 \%$ & & & & & \\
\hline German patentholder & $7.0 \%$ & $-2.5 \%$ & $-1.3 \%$ & $-4.1 \%$ & $0.9 \%$ & $6.5 \%$ & $-2.3 \%$ & $-2.6 \%$ & $-2.7 \%$ & $1.1 \%$ \\
\hline Same patent \& opposer country & $-2.2 \%$ & $-3.2 \%$ & $4.1 \%$ & $5.0 \%$ & $-3.8 \%$ & $-2.1 \%$ & $-3.1 \%$ & $4.4 \%$ & $4.9 \%$ & $-4.1 \%$ \\
\hline Multiple oppositions & $-10.7 \%$ & $9.6 \%$ & $-6.4 \%$ & $-10.3 \%$ & $17.9 \%$ & $-10.9 \%$ & $10.1 \%$ & $-5.8 \%$ & $-10.6 \%$ & $17.3 \%$ \\
\hline US twin exists & $4.2 \%$ & $-1.6 \%$ & $3.2 \%$ & $1.8 \%$ & $-7.6 \%$ & $4.8 \%$ & $-1.7 \%$ & $3.2 \%$ & $1.5 \%$ & $-7.8 \%$ \\
\hline Multiple US twins & $1.1 \%$ & $5.5 \%$ & $2.8 \%$ & $-1.0 \%$ & $-8.4 \%$ & $0.6 \%$ & $5.4 \%$ & $2.8 \%$ & $-0.3 \%$ & $-8.5 \%$ \\
\hline USPTO - Indep. Inventor & $7.2 \%$ & $0.2 \%$ & $-3.8 \%$ & $-0.6 \%$ & $-3.1 \%$ & & & & & \\
\hline
\end{tabular}

Entries in bold are significantly different from the rejection effects at the 5 percent level.

Entries in bold italics are significantly different from the rejection effects at the 10 percent level.

Bi-annual year dummies are included.

Only one (final) outcome per EPO patent included. 


\section{Figure 1}

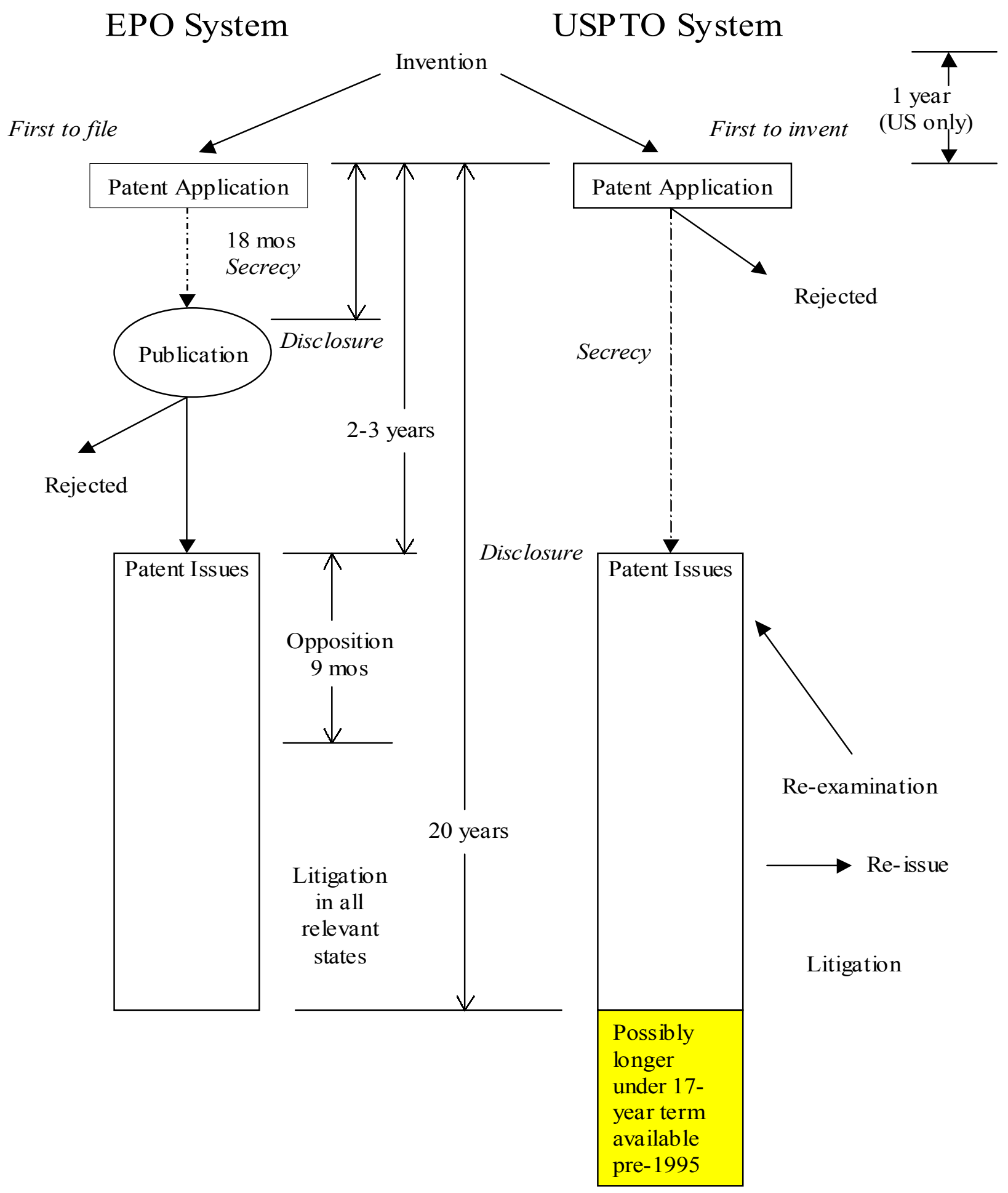


Figure 2

USPTO Re-exams and EPO Oppositions

by year of patent grant

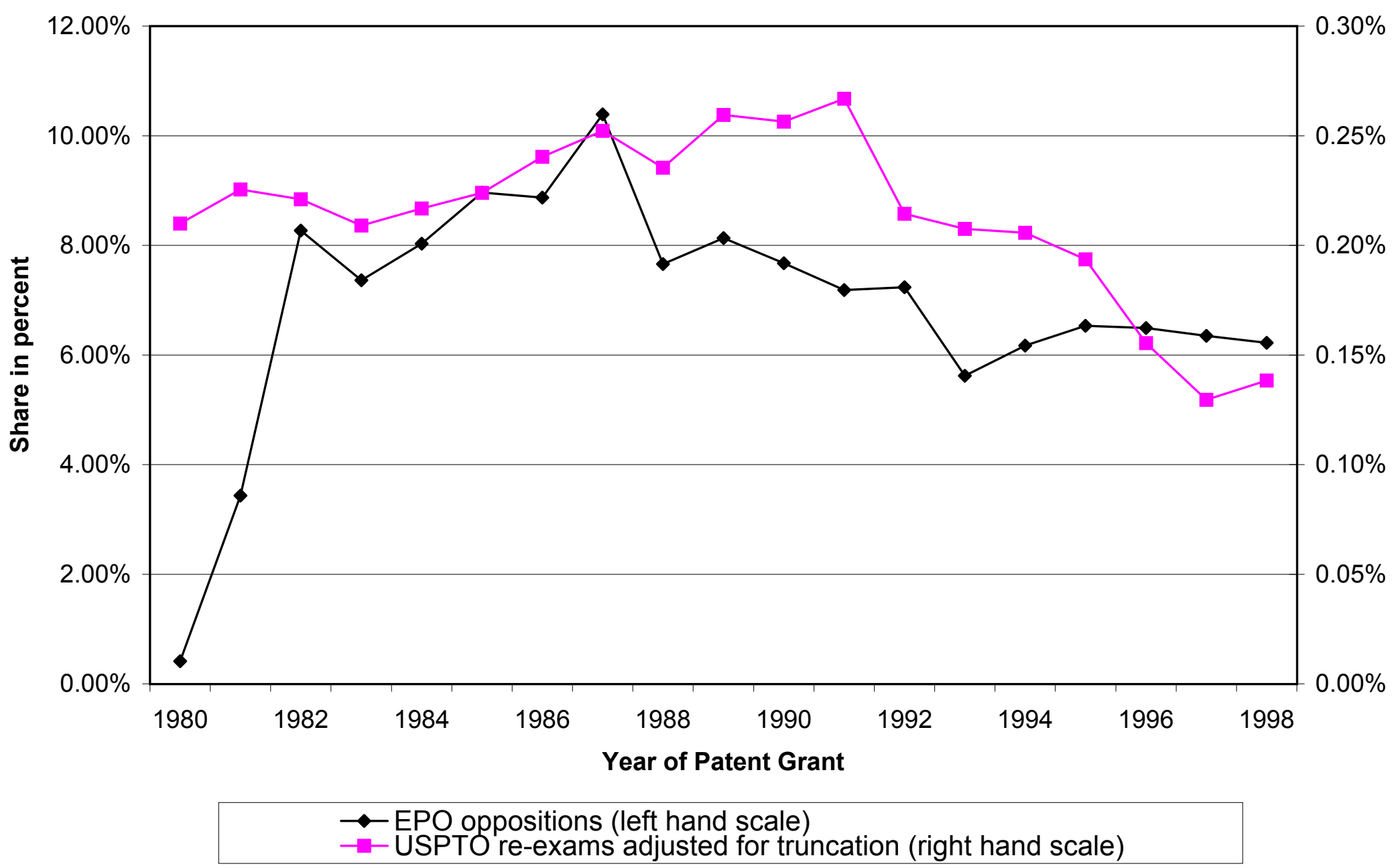


Figure 3

USPTO Re-examinations by Grant Year 1980-1996 Selected Technology Classes

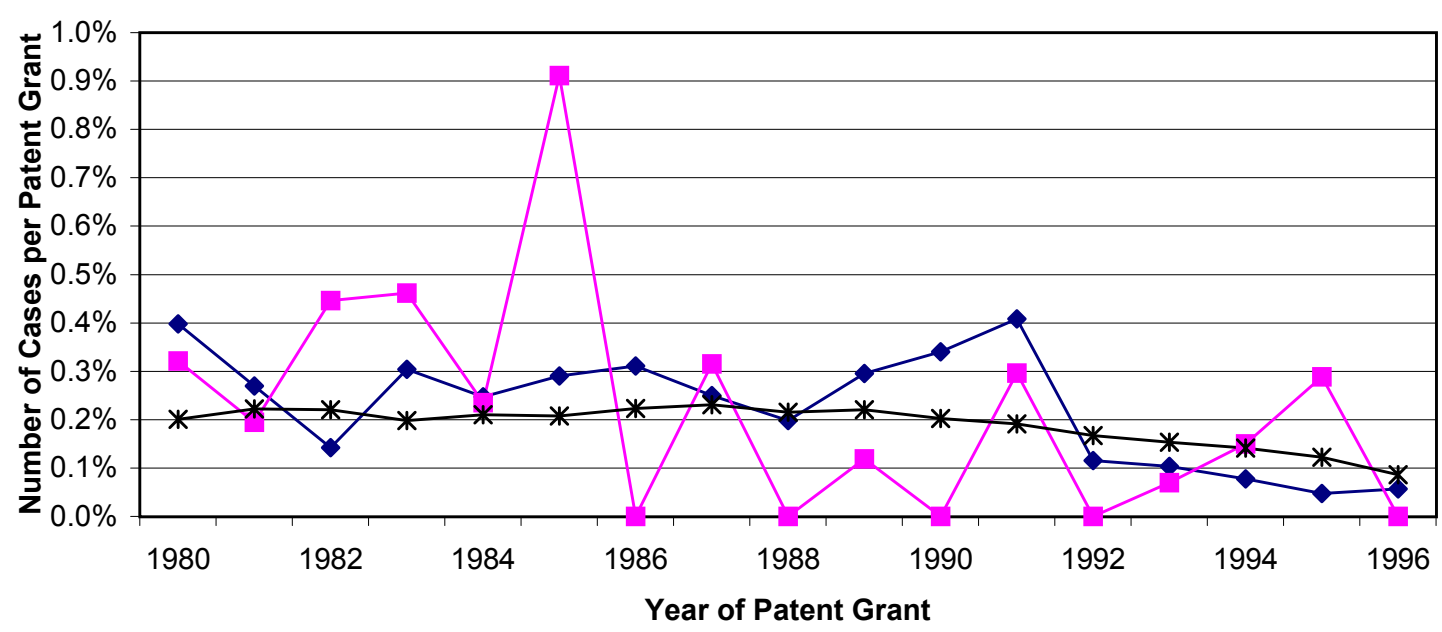

EPO Oppositions by Grant Year 1980-1996

Selected Technology Classes

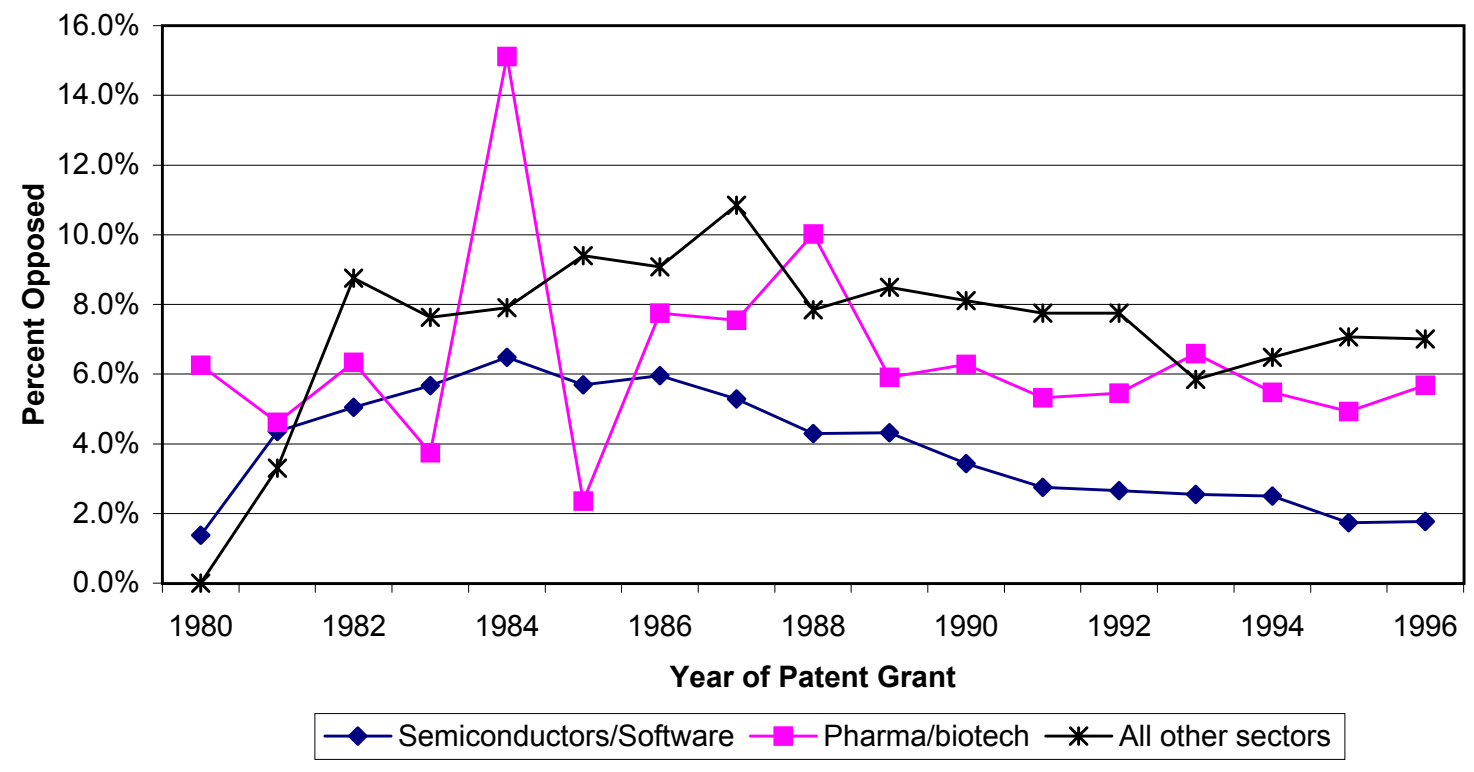


Figure 4

Lag between Application and Re-examination (adjusted)

USPTO 1981-2000

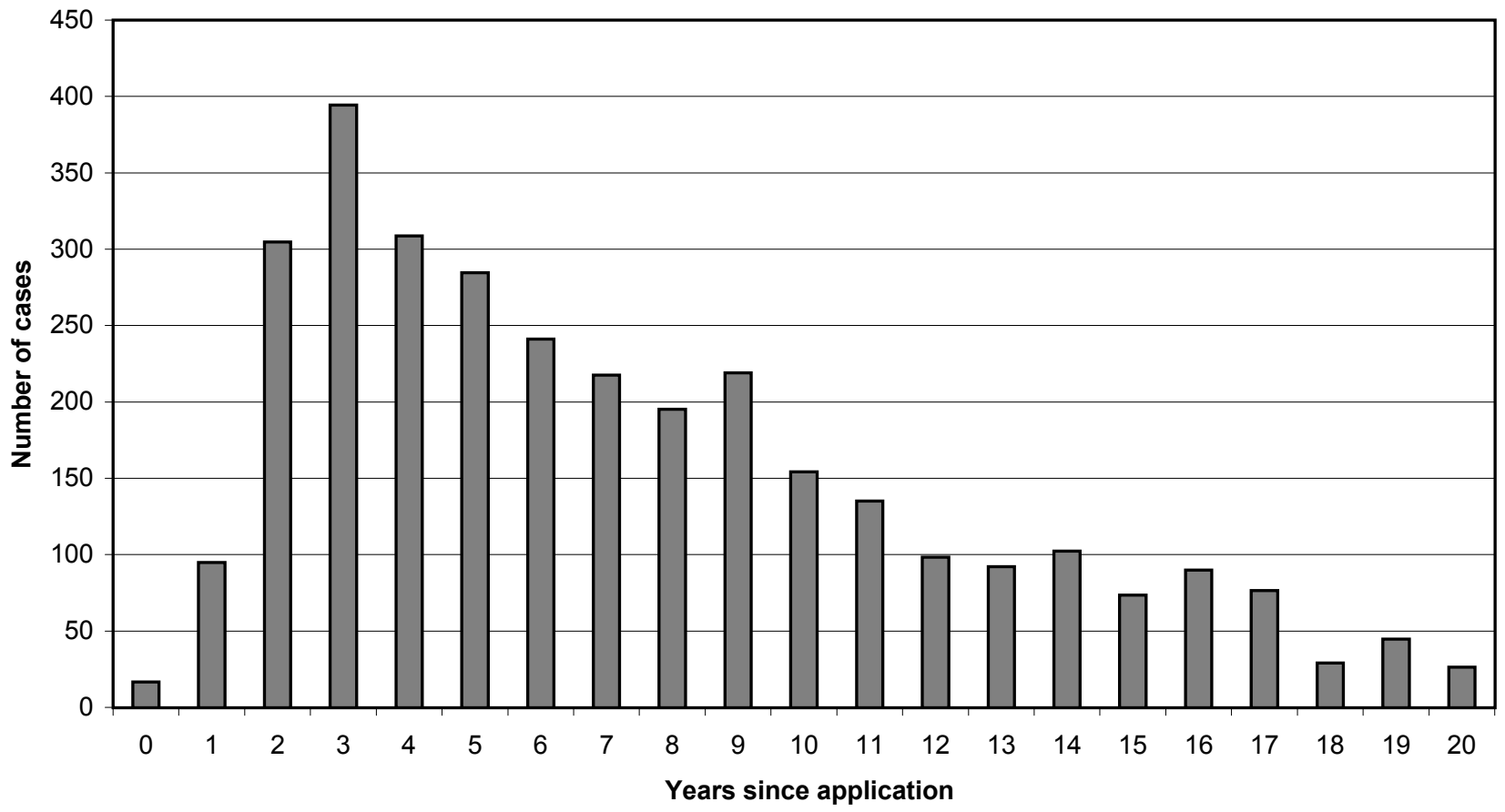

Lag between Application and Opposition

EPO 1978-1999

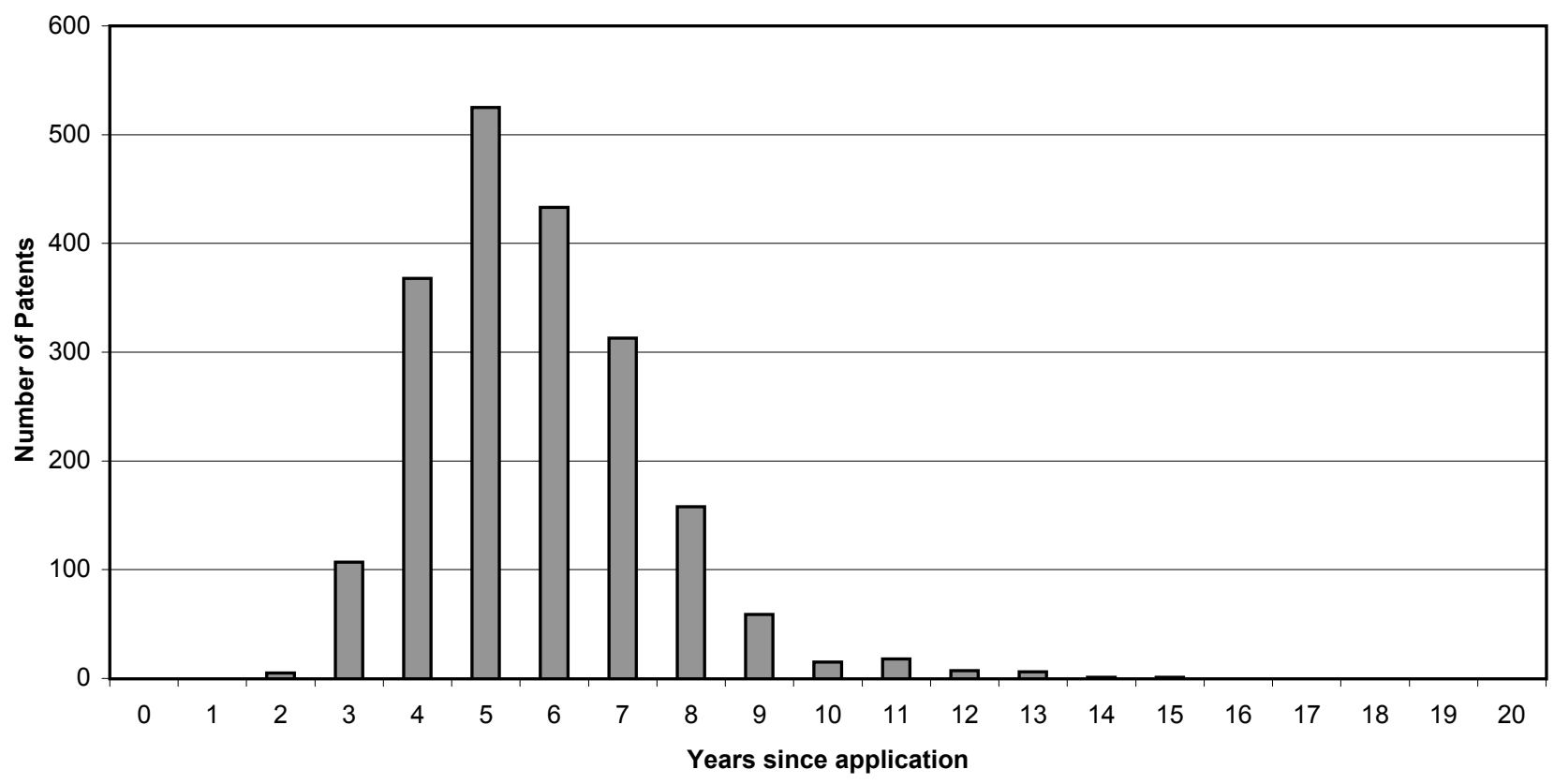


Figure 5

Lag between Application and Final Re-examination Outcome USPTO 1981-2000 (Patents granted 1975-1999)

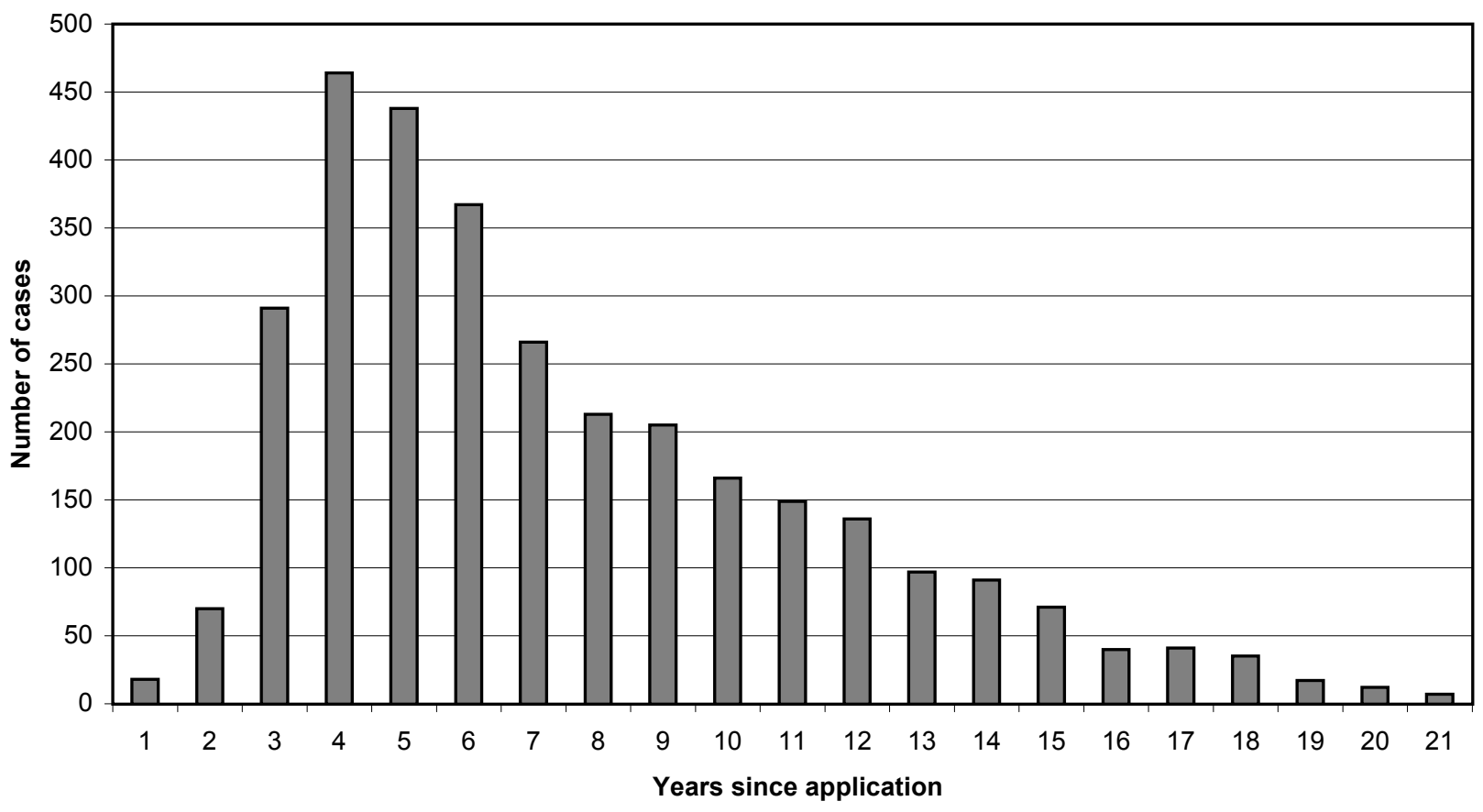

Lag between Application and Final Opposition Outcome Biotech/pharma/semiconductor/software classes only EPO 1978-1999 (Patents granted 1980-1997)

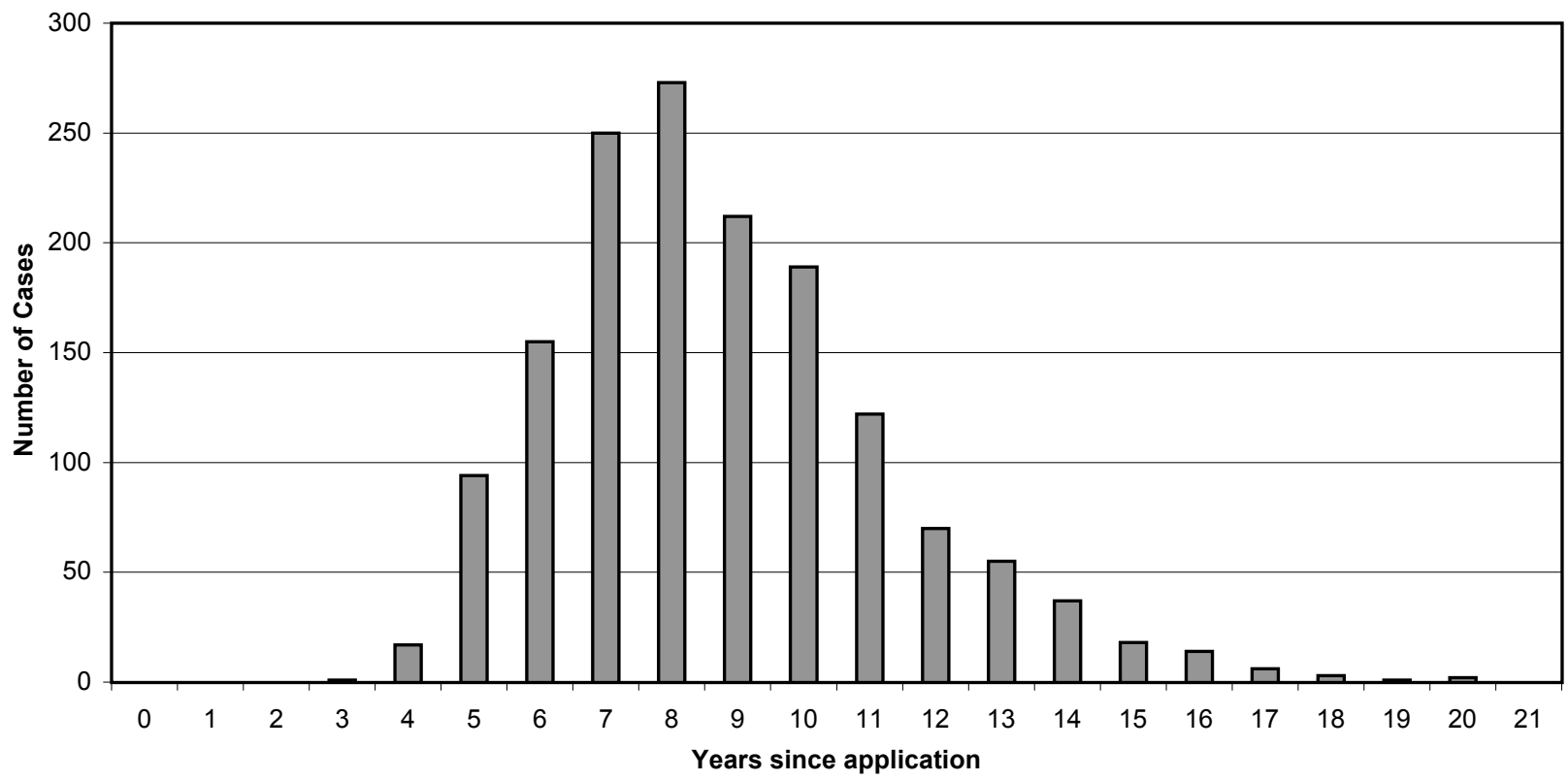


Figure 6

EPO-USPTO Twin Study

Sampling Strategy

\begin{tabular}{|c|c|}
\hline $\begin{array}{l}\text { EPO Opposed } \\
\text { Patents } \\
\begin{array}{c}\text { BP }-1,262 \\
\text { SS }-765 \\
\text { Total }-2,027\end{array}\end{array}$ & $\begin{array}{l}\text { EPO Control } \\
\text { Patents } \\
\text { BP - } 903 \\
\text { SS - } 1,958 \\
\text { Total }-2,861\end{array}$ \\
\hline & \\
\hline $\begin{array}{c}\text { USPTO Equivalents } \\
\text { to Opposed } \\
\text { Patents } \\
\text { BP - } 519(41.1 \%) \\
\text { SS - } 513(67.1 \%) \\
\text { Total - } 1,032(50.9 \%)\end{array}$ & $\begin{array}{c}\text { USPTO Equivalents } \\
\text { to Control } \\
\text { Patents } \\
\text { BP - } 459(50.8 \%) \\
\text { SS-1,486 (75.9\%) } \\
\text { Total }-1,945(68.0 \%)\end{array}$ \\
\hline
\end{tabular}

$\mathrm{BP}=$ biotechnology/pharmaceuticals

SS $=$ semiconductors/software/computers 
Figure 7

Sample of 2021 Opposed Patents

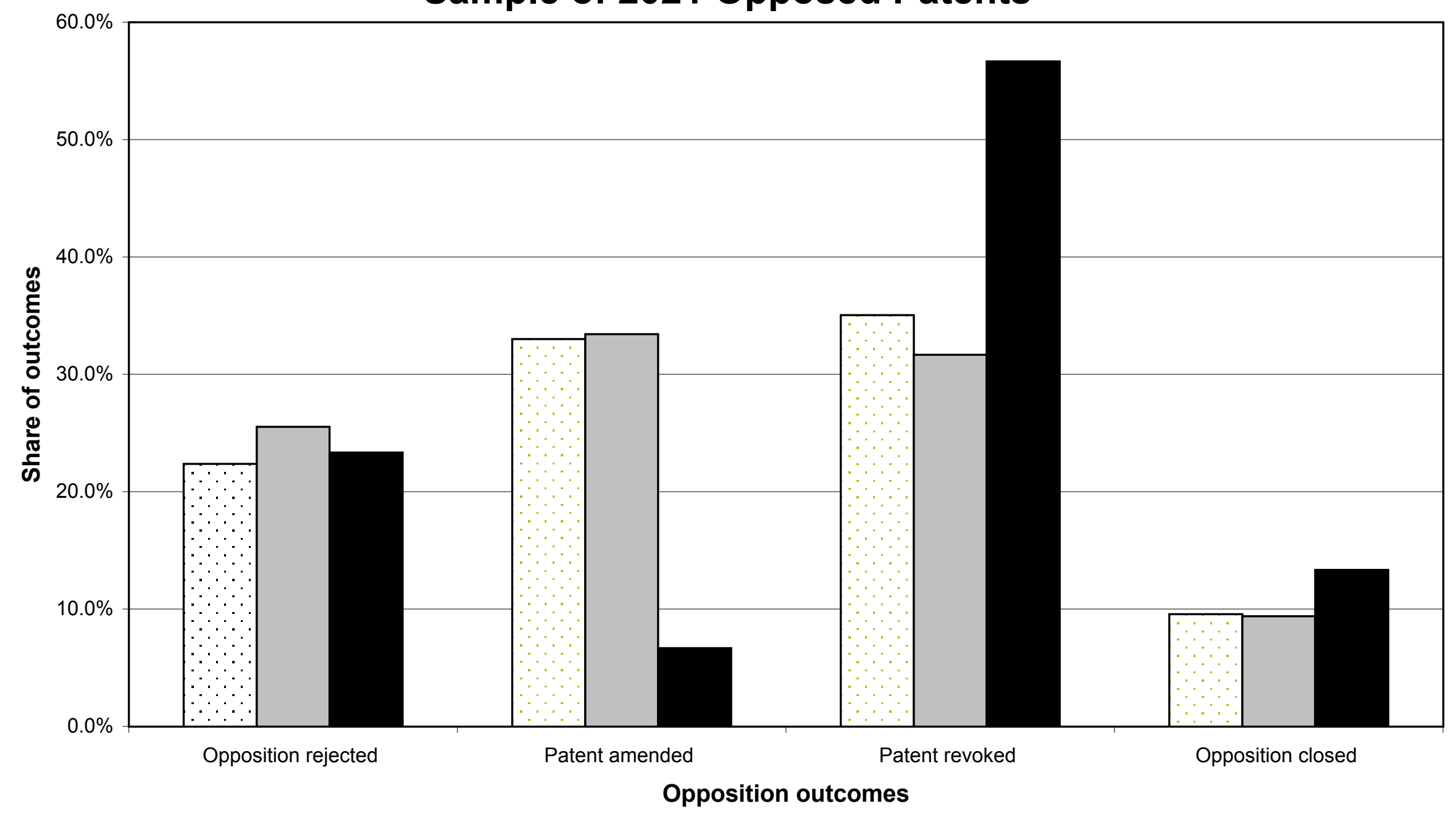

$\square$ All opposed patents $\quad \square$ Opposed patents with US twins $\quad$ Oopposed patents litigated in US 